EstAg 32 (1997) 217-266

\title{
Ga 6,2 en la obra agustiniana
}

En el capítulo sexto de su carta a los Gálatas escribe el Apóstol: (1) Hermanos, aun cuando alguno incurra en alguna falta, vosotros, los espirituales, corregidle con espíritu de mansedumbre, y cuídate de ti mismo, pues también tú puedes ser tentado. (2) Ayudaos mutuamente a llevar vuestras cargas y cumplid así la ley de Cristo. (3) Porque si alguno se imagina ser algo, no siendo nada, se engaña a sí mismo. (4) Examine cada cual su propia conducta y entonces tendrá en sí solo, y no en otros, motivo para glorificarse, (5) pues cada uno llevará su propia carga ${ }^{2}$.

De estos versillos, el que recibe mayor atención de parte de san Agustín es el segundo: Ayudaos mutuamente a llevar vuestras cargas y cumplid así la ley de Cristo. Será el que centre nuestro interés; los demás sólo en la medida en que aparecen asociados a él.

\section{LA PRESENCIA DE GA 6,2 EN LA OBRA AGUSTINIANA}

En el conjunto de la obra agustiniana hemos contabilizado 23 citas de dicho texto. Al respecto, se pueden distinguir tres épocas: antes del año 400, desde el 400 al 411, y después del 411. Con anterioridad al año 400 sólo lo cita tres veces: la primera en la Carta 22,9, del 392, referencia puramente circunstancial; la segunda en la Exposición de la carta a los Gálatas 58, en torno al 394; y la tercera en la cuestión 71 de las 83 diversas cuestiones, difícil de colocar cronológicamente con exactitud, pero ciertamente anterior al episcopado (a. 396).

Si hemos puesto como primer punto de referencia el año 400 , se debe a que en torno a esa fecha se puede colocar el inicio del período álgido de la controversia donatista. A este período corresponden los siguientes textos:

1. El tema fue estudiado hace ya más de veinticinco años por A.-M. La Bonnardière («Portez les fardeaux les uns des autres. Exégèse augustinienne de Ga 6,2», Didaskalia 1 [1971] 201-215). Pero eso no es óbice para volver sobre el mismo tema, con el fin de extraer mayor riqueza de los textos agustinianos. La brevedad del artículo de la docta francesa no se lo permitió a ella.

2. Traducción de la Biblia de Jerusalén 
Sermón 88,18,20, en torno al 400; Sermón 91,7,9 posterior al 400; Réplica a las cartas de Petiliano 3,5,6, de primeros del 403; Réplica a la carta de Parmeniano 3,2,5, de poco después del 404; La concordancia de los evangelistas 2,30,72, en torno al 405; El bautismo 2,6,83, no anterior al 405; uno de los nuevos sermones editados por F. Dolbeau, de finales del 4064; Tratados sobre la primera carta de Juan 1,12 y 10,4 del 407; Comentario al salmo 129,4.5 del 407; Comentario al Salmo 132,9, también del 407; Sermón 163 B (= Frangipane 5), dedicado íntegramente a comentar Ga 6,1-10, del 8 de septiembre del 410; Comentario al salmo 41,4, entre el 400 y el 410; Sermón 164, todo él dedicado también a la exposición de Ga 6,1-5, y Sermón 16 A (= Denis 20),7, ambos del 411. Dentro de este período hay que colocar también Trinidad 8,7,10, anterior al 412 , pero que queda fuera de la temática de la controversia.

Como segundo punto de referencia hemos puesto el 411, año en que se celebró la célebre Conferencia de Cartago que decretó la unidad entre católicos y donatistas. Aunque sus coletazos aún ocuparon a Agustín por algún tiempo, la fecha, unida también a la aparición en escena de Pelagio y Celestio, marca una inflexión en las preocupaciones del obispo de Hipona. A este tercer período corresponden sólo cuatro textos: Tratados sobre el evangelio de san Juan 17,9, del 414; la Carta 219,1, del 418; La ciudad de Dios 15,6, posterior al 418, y Retractaciones 51,26 , del 426 , texto sin importancia por tratarse sólo de una referencia a la cuestión 71 antes mencionada6.

Los datos dejan claro que el mayor trato del santo con ese texto acontece durante el período en que la controversia con los donatistas adquirió su máxima intensidad. Y, como es comprensible, la controversia se dejará notar, sin duda, en su interpretación.

\section{EL TEXTO LATINO}

Respecto de Ga 6,2, el versillo que nos ocupa, las páginas agustinianas ofrecen en latín dos lecturas diferentes. La primera -Invicem onera vestra por-

3. Este texto no aparece en el elenco de A.M. La Bonnardière, art. cit. p. 201.

4. Sermo sancti Augustini de his qui se ad unitatem cogi conquerentur, contra partem Donati, 1, en Revue des Études Augustiniennes 37 (1991) 303-306; en concreto, p. 303.

5. Usaremos las siguientes abreviaturas: Para la Exposición de la carta a los Gálatas, ExpGa; para 83 Diversas cuestiones, 83DQ; para La Concordancia entre los evangelistas, ConEv; para Réplica a las cartas de Petiliano, RepPet; para Réplica a la carta de Parmeniano, RepPar; para Tratados sobre la primera carta de Juan, TrCaJn; para Comentario al Salmo, ComSal; para Tratados sobre el evangelio de san Juan, TrEvJn; para La ciudad de Dios, CiudD.

6. A.-M. La Bonnardière añade el Sermón 340,1. Nosotros lo excluimos puesto que se trata de un sermón de $\mathrm{S}$. Cesáreo de Arlés, aunque con material agustiniano. 
tate, et sic (ad)implebitis legem Christi- se encuentra en los siguientes textos: 83DQ; RepPet; RepPar; Sermón 91; ConEv; ComSal 41; TrCaJn 1,12(2); TrEvJn; Sermón 164; Trinidad; CiudD; Retractaciones 1,26; ComSal 129(3); Sermón 163 B,3; Sermón 16 A,7. La segunda-Alter alterius onera portate et sic (ad)implebitis legem Christi- se halla en estos otros: ExpGa; RepPar; Sermón 88; ComSal 129,4; Sermón 163 B,1.4; Carta 219. Al respecto hay que anotar dos particulares: que en todos estos casos $\mathrm{Ga} 6,2$ va precedido de $\mathrm{Ga}$ 6,17, y que a veces en un mismo texto aparecen ambas lecturas, primero con alter alterius, y luego con invicem. Se obtiene la impresión de que el códice de que disponía tuviese alter alterius, pero él estuviese familiarizado con la fórmula del invicem que le sale espontánea en el comentario. Esto aparece claro en el sermón 163 B. Al comienzo, el orador cita íntegro Ga 6,1-10 con la lectura alter alterius, pero luego en el comentario siempre abandona dicha fórmula en favor del invicem, salvo una vez, en el n. 4, en que da la impresión de que estuviese leyendo el texto: «Después de haber puesto sobre aviso a los espirituales introdujo (intulit) la sentencia de alcance general: Alter alterius...». Algo parecido acontece en el ComSal 129,4-5 y en la RepPar 3,2,5.

\section{ORQUESTACIÓN BÍBLICA}

Principio fundamental de la exégesis patrística en general y de la agustiniana en particular es el de «explicar la Biblia por la Biblia», considerándola como una unidad doctrinal y hasta cierto punto literaria. Aun reconociendo la diversidad de autores humanos, en última instancia ve a Dios como su único y último autor. A partir de ahí, un primer paso necesario o, al menos, conveniente, para comprender la interpretación que da el obispo de Hipona del precepto paulino que nos ocupa, es examinar los otros textos bíblicos de que se sirve para exponer su significación y aquellos otros con los que, de forma más o menos directa, aparece asociado en sus escritos.

Sólo en tres casos, Carta 22, ConEv y ComSal 41, Ga 6,2 no aparece vinculado a ningún otro texto bíblico. En la mayoría de los casos en que se encuentra asociado a otras citas bíblicas, Ga 6,2 está al servicio de la explicación de las mismas o de los conceptos a los que dichas citas sirven. Sólo en cuatro pasajes $\mathrm{Ga}$ 6,2 constituye el objeto directo del comentario. El primero de ellos es ExpGa 58. Aquí Ga 6,2 arrastra consigo la referencia a Lv 19,18

7. A.M. La Bonnardière limita esa praxis al decir «particulièrment dans les textes où le verset $\mathrm{Ga}$ 6,2 est inmédiatement précédé du verset $\mathrm{Ga}$ 6,1» (art. cit. p. 201). En realidad sobran los dos adverbios, pues el hecho se da siempre que $\mathrm{Ga} 6,2$ va precedido de $\mathrm{Ga} 6,1$. 
(Amarás a tu prójimo como a ti mismo) y a Rom 13,8-9 (Pues el que ama ha cumplido la ley... La caridad es, por tanto, la ley en su plenitud) y a Mt 5,17 (No he venido a abolir la ley, sino a darle cumplimiento). Los conceptos que orientan la selección de los textos son la ley y el amor.

El segundo es la cuestión 71 de las $83 D Q$. El primer texto a que recurre para exponer Ga 6,2 es Jn 13,34-35 (... que os améis los unos a los otros; en esto conocerán todos que sois discípulos mios). Luego, la mención de los ciervos, cuyo comportamiento presenta como ejemplo práctico de lo que ordena el Apóstol, le lleva a citar Pr 5,19 [LXX] (El ciervo de la amistad y el vástago de tus gracias dialoguen contigo). A continuación propone como modelo a Cristo, y cita Flp 2,4-8 (Tened los mismos sentimientos... y una muerte de cruz); a Pablo, y cita 1 Co 9,22 (Me hice todo para todos, para ganarlos a todos) y Flp 2,3 (Nada hagáis por rivalidad o vanagloria, sino estimando cada cual con humildad de alma que el otro es superior a él). Para señalar el modo de tratar a los pecadores, trae a colación Mt 9,12 (No necesitan del médico los sanos, sino los enfermos), Mt 7,1-2 (No juzguéis y no seréis juzgados; con la medida con que juzguéis seréis juzgados) y, por último, 1 Co 8,11 (Y por tu ciencia perecerá el hermano débil, por quien murió Cristo). La idea orientadora es, de nuevo, globalmente la del amor.

El tercero es el sermón $163 \mathrm{~B}$, dedicado en su totalidad a comentar $\mathrm{Ga}$ 6,1-10. En él recurre a Mt 6,12 (Perdónanos nuestras ofensas), Sb 9,15 (el cuerpo corruptible es lastre para el alma), Jb 7,1 (La vida en la tierra es toda una prueba); 2 Co 6,1 (Os mandamos y exhortamos a no recibir en vano la gracia de Dios) y Sal 9,3 (El pecador es alabado en los deseos de su alma). Son conceptos guía los del pecado, del que nadie está exento, y el del perdón.

El cuarto y último es el sermón 164, dedicado también enteramente a comentar Ga 6,1-5, poniendo el énfasis en mostrar que no hay contradicción entre los versillos 2 y 5 . No obstante ser relativamente largo, en la parte de comentario de $\mathrm{Ga} 6$, el sermón cuenta con sólo tres citas bíblicas: Mt 11,28-30 (Venid a mi todos los que estáis cansados y cargados y yo os aliviaré), $1 \mathrm{Tm}$ 6,17-19 (Manda a los ricos de este mundo... para que alcancen la vida verdadera) y 1 Co 11,29 (Pues quien lo come y bebe indignamente come y bebe su propia condenación). El predicador pone el énfasis en distinguir las clases de cargas y en el compartir las riquezas.

Como ya se señaló, en los restantes pasajes Ga 6,2 aparece al servicio de la comprensión de otros pasajes bíblicos o conceptos. De estos, el más frecuente es el del amor. En los dos pasajes de los TrCaJn sigue un mismo procedimiento, articulado en cuatro momentos: versillo de la Carta de san Juan, salmo, evangelio de Juan y texto de $\mathrm{Ga}$ 6,2. En $\operatorname{TrCaJn} 1,12$, la exposición de $1 \mathrm{Jn} 2,10$ (Quien ama a su hermano permanece en la luz y no sufre escándalo) 
le evoca la cita de Sal 118,165 (Haya paz abundante para los que aman tu ley, y no se escandalizan) ${ }^{8}$; luego, la mención de la ley le trae a la mente Jn 13,34 (Os doy un mandamiento nuevo: que os améis unos a otros) y, por último, Ga 6,2, aunque precedido de Ef 4,2-3 (Soportándoos recíprocamente por amor, procurando guardar la unidad del espíritu en el vínculo de la paz). En TrCaJn 10,4 expone 1 Jn 5,2 (conocemos que amamos a los hijos de Dios, si amamos a Dios y cumplimos sus mandamientos). La ponderación del amor a Dios le conduce a Sal 118,85 (los deleites de los injustos no son comparables con la ley de Dios) y, como en el texto anterior, la mención de la ley le hace derivar al precepto de Jn 13,34 y éste a la ley de Ga 6,2.

En RepPar 3,1,1-2,4 san Agustín ha expuesto 1 Co 4,21-5,5 (¿Qué preferís, que vaya a vosotros con palo o con amor... a fin de que el Espíritu se salve en el Día del Señor $)^{9}$. En 3,2,5 vuelve sobre 1 Co 5,5. La ambigüedad del texto de 1 Co 5,2 ( $Y$ vosotros llenos de jactancia) la resuelve interpretando que se trata de un reproche; ve la prueba en el v. 6 (un poco de fermento corrompe toda la masa). La soberbia da razón de 1 Co 10,12 (El que crea estar en pie, mire no caiga). 1 Co 10,12 le lleva a Ga 6,1-2, que invita nuevamente a la precaución e indica cómo se ha de cumplir la ley de Cristo; esta cita, a su vez, le conduce a Jn 13,34 y a 14,27 (Mi paz os dejo, mi paz os doy), que especifican que se trata de la ley del amor que define a los cristianos y la paz asociada a Cristo; por último, uno y otro texto le llevan a Ef 4,2-3, que aúna en sí los conceptos fundamentales de las dos referencias bíblicas anteriores, el amor y la

8. Pasamos por alto la cita de Sal 120,6: El sol no te quemará de día ni la luna de noche. En el sol ve a Cristo que quema de día a quienes hallan escándalo en él, conforme a Jn 6,5469 (escándalo a propósito del discurso eucarístico), y en la luna a la Iglesia que quema de noche a los cismáticos, lo que le trae a la mente 2 Co 11,29 (¿Quién se escandaliza sin que yo me queme?).

9. Trata de justificar la disciplina eclesiástica poniéndola al servicio de la unidad. En concreto se propone refutar la utilización que en su favor hacía de 1 Co 5,13 (Apartad el mal de en medio de vosotros) el obispo donatista Parmeniano. Primero explica el pasaje desde su contexto inmediato con la ayuda de $1 \mathrm{Tm} 5,22$ (No te hagas cómplice de los pecados ajenos) y luego desde el contexto más amplio de 1 Co 4,21-5,5, donde el Apóstol ordena a los corintios tratar con severidad a un incestuoso, a la vez que les reprocha no haber hecho duelo. El reproche lo fundamenta en 1 Co 12,26 (si sufre un miembro, todos los demás sufren con él). La mención por el Apóstol del interitum carnis, le evoca Hch 5,5.10 (muerte de Ananías y Safira), Col 3,5 (mortificar los miembros terrenos) y Rom 8,13 (dar muerte a las obras del hombre carnal). Señala que la exclusión de la sociedad fraterna no implica la exclusión de la caridad y como prueba aduce 2 Ts 3,14-15 (señalar al pecador y no mezclarse con él; eso no es trato a un enemigo, sino corrección a un hermano). Que, a pesar de esa dureza, el Apóstol obraba impulsado por la caridad lo prueba Ef 4,2-3, 2 Ts 3,16 (pide a Dios les conceda la paz) 2 Co 12,21 (llanto por los que pecaron y no se convirtieron); 2 Co 13,2 (aviso de que actuará sin miramientos) y 2 Co 2,4-11 (amor y perdón). 
paz. Y al poner a Cristo como ejemplo, trae a colación Mt 9,12 y 1 Co 5,7-8 (Nuestra Pascua, Cristo, ha sido inmolada... con ázimos de pureza y verdad).

Exponiendo en los $\operatorname{Tr} E v J n$ la curación del enfermo en la piscina de Betsaida, el predicador se detiene en el particular de que llevaba treinta y ocho años enfermo. En esos treinta y ocho años encuentra simbolizada precisamente la enfermedad. El punto de partida es el simple cálculo matemático de que la cifra de treinta y ocho resulta de restar dos a cuarenta. En este número ve figurada la perfección a que conduce el cumplimiento de la ley, y ello le evoca Mt 5,17. La idea del cumplimiento de la ley le lleva a Rm 13,10 (La plenitud de la ley es la caridad) y a Rm 5,5 (La caridad derramada en nuestros corazones por el Espíritu Santo que se nos ha dado). A su vez, en el número dos ve simbolizado el doble precepto del amor y le evoca Mt 22,3740 (Amarás al señor tu Dios... penden toda la ley y los profetas); Lc 21,2-4 (vio también a una viuda pobre... cuanto tenía para vivir); Lc 10,35 (Sacando dos denarios, se los dio al posadero) y Jn 4,40 (Los samaritanos le rogaron que se quedase con ellos y se quedó dos días). Por otra parte, la necesidad que tenía el enfermo de un hombre que le metiese en la piscina le sugiere $1 \mathrm{Tm}$ 2,5 (Hay un solo Dios, y también un sólo Mediador entre Dios y los hombres, el hombre Cristo Jesús), y a las palabras que dirige al enfermo: toma tu camilla y camina, que interpreta también como símbolo del doble precepto del amor. Sirviéndose de 1 In 4,20 (Quien no ama a su hermano a quien ve, no puede amar a Dios a quien no ve), Jn 1,18 (a Dios nadie le ha visto nunca), 1 Jn 4,16 (Dios es amor y quien permanece en el amor permanece en Él) e Is 58,7-8 (Reparte tu pan con el hambriento... y no desprecies a tus parientes de sangre), muestra la relación entre ambos preceptos. Por último, concluye que, a su parecer, el toma tu camilla (Jn 5,8) simboliza el amor al prójimo, argumentando con Ga 6,2 y Ef 3,2-4, y el camina, el amor a Dios en cuanto que todo cristiano está en camino hacia él10.

Todavía hay otro pasaje en que vincula $\mathrm{Ga} 6,2$ con nuevos textos relativos al amor. En La Trinidad asocia Ga 6,2 con Ga 5,14 (Toda la ley se resume en este solo precepto: Amarás a tu prójimo como a ti mismo) y Mt 7,12 (Todo lo que queráis que os hagan a vosotros los hombres, hacedlo vosotros a ellos; esta es la ley y los profetas). Todos tienen en común el recomendar únicamente el amor del prójimo. El santo pretende mostrar que, aunque a veces la Escritura recomiende sólo el amor al prójimo, en ese amor al prójimo está incluido también el amor a Dios: no se puede amar al prójimo sin amar el amor con que se le ama y ese amor es Dios, como afirma san Juan ( $1 \mathrm{Jn}$ 4,8.16). Paralelamente antes ha citado otros textos que ordenan sólo el amor

10. $\operatorname{TrEvJn} 17,6-9$. 
de Dios (Rom 8,28; 1 Co 8,3; Rom 5,5) para señalar que también allí está implícito el amor al prójimo. En efecto, no se puede amar a Dios y dejar de cumplir sus mandatos, uno de los cuales es el de amar al prójimo11.

En la obra El Bautismo san Agustín muestra a los donatistas cómo en tiempos de san Cipriano no se rompió la unidad de la Iglesia a pesar de la seria discrepancia que mantenía él con otros colegas en el episcopado a propósito del bautismo de los herejes. De ahí concluye que es la Católica, no la Iglesia donatista, la sucesora de la Iglesia de Cipriano, citando Ga 6,2, Ef 4,3 y Flp 3,15: «La unidad católica alberga en su seno materno a todos los que llevan recíprocamente sus cargas y se afanan por conservar la unidad del espíritu en el vínculo de la paz, hasta que el Señor revele a una de las partes que no se encuentra en la verdad»12.

Junto al del amor, otro de los temas recurrentes es el de la corrección. En el sermón 88 le ocupa el tema, tan específico de la controversia donatista, de que los malos no contaminan a los buenos, si éstos no consienten a las malas acciones de aquellos. Como prueba aduce Ef 5,11 (no comulgar con las obras infructuosas de las tinieblas y redargüirlas), que señala la doble actitud que se debe tomar ante el pecado ajeno: no comulgar con el pecado y corregir al pecador. De ahí procede a indicar cómo debe efectuarse la corrección para lo cual cita 1 Co 10,12 (El que crea estar en pie, mire no caiga), que le lleva a Ga 6,1-2 y 2 Tm 2,24-26 ( $A$ un siervo del Señor no le conviene ser pendenciero... que corrige con modestia a los que piensan diversamente... cautivos sujetos a su voluntad) ${ }^{13}$. La Carta 219 que tiene por autores a cuatro obispos, uno de los cuales es san Agustín, va dirigida a otros dos obispos y se ocupa del monje Leporio. En su primer número señalan cómo todos, mitentes y destinatarios, han cumplido el precepto apostólico de 1 Tes 5,14 (Corregid a los inquietos, animad a los pusilánimes, sostened a los débiles y sed pacientes con todos. Mirad que nadie devuelva mal por mal); los destinatarios, al corregir a monje; los mitentes al consolarlo y acogerlo, y cita Ga 6,1-214. En el libro quince de CiudD trata de la enfermedad que sufre el hombre como consecuencia del pecado original; enfermedad que no es, pues, fruto de la naturaleza, sino de un vicio. Eso implica que admite superación. Por esa razón, argumenta, a los que progresan y viven en la peregrinación de esta vida se les da una serie de preceptos. El primero que señala es Ga 6,2, al que luego añade otros: 1 Ts 5,14-15 (... Que nadie devuelva a otro mal por mal, antes bien, procurad siempre el bien mutuo y el de todos); Ga 6,1, Ef 4,26 (Que el sol no caiga sobre

11. Trinidad $8,7,10$.

12. El bautismo 2,6,8.

13. Sermón $88,18,19-20$.

14. Carta 219,1. 
vuestra ira), Mt 18,15 (Si tu hermano peca contra ti, corrígele a solas), $1 \mathrm{Tm}$ 5,20 (A los pecadores censúrales en público, para que también los demás teman) y Mt 18,23-35 (... Pues de igual modo os tratará mi Padre del cielo si no perdonáis cada uno de corazón a su hermano), amén de Hb 12,14 (Procurad la paz con todos..., sin la cual nadie verá al Señor).

Hay todavía otro pasaje en que el santo vincula $\mathrm{Ga}$ 6,2 con citas bíblicas alusivas al perdón. Es el ComSal 129. En el tercer versillo el salmista se dirige a Dios con estas palabras: Si tienes en cuenta los delitos, ¿quién podrá resistir?, y en la segunda parte del cuarto con estas otras: Gracias a tu ley he podido resistirte. ¿De qué ley se trata? En un primer momento la identifica con la que él llama «ley de la misericordia» de Mt 6,12 u obligación de perdonar para recibir el perdón; luego con Ga 6,2, que posteriormente vuelve a citar junto el versillo primero del salmo. Además, para poner un ejemplo de cómo el pecado ajeno sólo contagia si se asiente a él, trae a colación Sal 49,18 (asociarse al ladrón), y luego vuelve a unir Mt 6,12, Ga 6,2 y Sal 129,4b (Gracias a tu ley he podido resistirte) (ComSal 129,4). En el número siguiente, señalando que todo hombre es pecador, asocia Mt 5,22 (será reo de la gehena del fuego), Sal 129,1-3, 1 Jn 3,4 (El pecado es la iniquidad) y, de nuevo, Ga 6,2 y Mt 6,1215.

En la RepPet invitaba a los fieles a que no siguiesen a hombres, por ilustres que fueran, sino a Dios. Comenzaba con 1 Co 3,7 (Ni el que planta ni el que riega es algo, sino Dios que hace crecer) y seguía con 1 Jn 4,16 (Dios es amor y quien permanece en el amor permanece en Dios); con Ga 6,4-5; con $\mathrm{Rm}$ 14,12-13 (Cada uno de vosotros dará cuenta de sí. Dejemos, por tanto, de juzgarnos los unos a los otros), Ga 6,2-3; Ef 4,2-3 y Mt 12,30 (quien no recoge, desparrama) ${ }^{16}$.

En el sermón 16 A,7 se propone explicar Sal 38,2 (Puse guardia a mi boca, mientras el pecador se enfrentó a mí). El tener que soportar la calumnia levantada por el pecador le mueve a citar 2 Co 1,12 (nuestra gloria es el testimonio de nuestra conciencia), a aludir a Ga 6,1 y luego a citar Ga 6,2. La idea central que quiere trasmitir es que no hay que devolver mal por mal.

En el sermón 91 Ga 6,2 aparece como conclusión de un período que comenzaba con 2 Co 5,6-7 y 1 Co 13,12 (caminamos en la fe mientras dura esta peregrinación, hasta que lleguemos a la realidad en que le veamos cara a cara). Pero, aunque no lo cite, el contenido que desarrolla entre ambas citas está inspirado todo él por Mt 25,34-40. La idea central y única es la de compartir'17.

15. ComSal 129,5.

16. RepPet. 3,5,6.

17. Sermón $91,7,9$. 
Por último, en Comentario al salmo 132,9, Ga 6,2 es utilizado por san Agustín para exponer Sal 132,1-2.

Tras el análisis, procede ofrecer en síntesis los datos más significativos. El primero es que el santo asocia repetidas veces $\mathrm{Ga} 6,2$ con $\mathrm{Jn}$ 13,34-3518. La relación entre Ga 6,2 y Jn 13,34-35 le resultaba fácil: por un lado, mediante la equiparación entre lex y mandatum; por otra, a través de la presencia en ambos del concepto de reciprocidad y del término invicem que lo expresa. Otro texto al que aparece asociado es Jn 14,27: Os dejo la paz, mi paz os dejo.

Siempre con referencia a la ley de Cristo, no son Jn 13,34-35 y 14,27 los únicos textos que llegan en socorro del comentarista. Los conceptos claves de esos dos textos del evangelio de Juan, el amor y la paz, aparecen juntos en Ef 4,2-3: Soportándoos mutuamente unos a otros en el amor, poniendo empeño en conservar la unidad del Espíritu con el vínculo de la paz. Eso explica, entre otros datos, la frecuencia con que aparece asociado a $\mathrm{Ga}$ 6,2: nada menos que siete veces, $y$ todas ellas en textos que se ubican en el período dominado por la controversia donatista19. El santo considera ambos textos idénticos. A Parmeniano se lo dice con toda claridad: en $\mathrm{Ga}$ 6,2 Pablo dice exactamente lo mismo que en Ef 4,2-320. Varios factores favorecían la asociación. El primero, de nuevo, la presencia en ambos casos del concepto de reciprocidad y del término invicem que la expresa; luego el paralelismo semántico entre el onera portare y el sufferentes; la mención en el segundo del amor que el primero lleva implícito en el concepto de la «ley de Cristo». Al mismo tiempo, este segundo, con la mención de la unidad, el Espíritu y la paz, le servía para poner el primero al servicio de los conceptos fundamentales de la paz y la unidad cuyo logro impulsaba su labor contra los cismáticos. El texto le servía de puente para introducir Ga 6,2 en el contexto de la polémica. La asociación llega de forma a veces elaborada mediante una cadena de conceptos. Una muestra significativa la tenemos en RepPar con el siguiente esquema: $1 \mathrm{Co}$ 10,12 (invitación a la precaución) le lleva a Ga 6,1-2 (precaución más ley); la ley de Ga 6,2 le lleva a Jn 13,34 (precepto del amor) y a Jn 14,27 (la paz de Cristo) y, por último a Ef 4,2-3 (amor y paz) como síntesis de los dos últimos textos. Partiendo de que la ley de Cristo es el amor, es lógico que aporte los numerosos textos señalados que hablan explícitamente del amor o él los interpreta como significando el amor.

Ga 6,2 aparece también repetidamente asociado a citas bíblicas que se refieren a los conceptos de corrección y de perdón; establece un principio

18. 83DQ 71,1; RepPar 3,2,5 [2 x]; TrCaJn 1,12; 10,4 .

19. RepPet 3,5,6; Sermón 88,19,21; Baut 2,6,8; RepPar 3,2,5 [2 x], en $\operatorname{TrCaJn} 1,12, \operatorname{Tr} E v J n$ 17,9 .

20. RepPar 3,2,5. 
general que luego se concreta en esas dos formas. Vinculados al tema de la corrección hemos visto aparecer diversos textos del Nuevo Testamento: $\mathrm{Mt}$ 18,15; 1 Co 10,12; Ef 5,11; 1 Tm 5,20; 2 Tm 2,24-26; 1 Ts 5,14-15; y con el del perdón estos otros: Mt 6,12; 9,12; 18,23-35; Ef 4,26. En ambos casos el puente natural ha sido Ga 6,1, explicitado o no, con su exhortación a corregir al pecador y a estar precavidos ante la posibilidad de pecar.

Negativamente sorprende el poco peso que ha tenido la palabra onera a la hora de orientar la selección de los textos explicativos. Sólo en el sermón 164 conecta con Mt 11,28-30: Venid a mí todos los que estáis cargados... mi carga (onus-sarcina) es ligera.

\section{LA LEY DE CRISTO}

Vistos los textos bíblicos asociados por el obispo de Hipona a Ga 6,2, procede ocuparse ya de la explicación que ofrece de los conceptos más importantes del versillo: las cargas que hay que llevar y la ley que hay que cumplir. Comenzamos por la ley.

¿A qué ley entiende él que se refiere el apóstol? La pregunta ya quedó contestada indirectamente en el apartado anterior. Según el santo, el Apóstol se refiere al precepto dado por Cristo específicamente para sus discípulos y que se constituye en criterio que los identifica como tales: En esto conocerán todos que sois mis discípulos: si os amáis unos a otros como yo os he amado (Jn 13,35).

La identificación de la ley de Cristo con el precepto del amor recíproco es constante. Aparece ya en sus dos primeros comentarios al texto ${ }^{21}$. En el segundo período, ya en plena controversia donatista, no hace sino repetirlo una y otra vez: en la RepPar 3,2,5; en los TrCaJn 1,12 y 10,4, en el ComSal 129,4; en el Sermón 163 B,2. En el tercer período, en los TrEvJn 17,9. En algunos de estos textos se limita a afirmar genéricamente que se refiere a la ley del amor; en otros hace mención explícita de Jn 1,34(-35)22. La identificación la considera tan plena que puede sustituir sin más ley por caridad. Así dice: «La ley de Cristo es la caridad, y sólo se cumple la caridad si llevamos recíprocamente nuestras cargas» 23 . Para él no ofrece dudas. Una veces lo afirma taxativamente; otras, mediante una pregunta puramente retórica: ¿Es que la ley de Cristo consiste en otra cosa que en las palabras: Os doy un mandato

21. $\operatorname{Exp} G a 58$ y $83 D Q 71,1$.

22. $83 D Q 71,1 ; \operatorname{RepPar} 3,2,5 ; \operatorname{Tr} C a J n 1,12 ; 10,4$.

23. $\operatorname{Tr} E v \operatorname{Jn} 17,9$. 
nuevo: que os améis los unos a los otros (Jn 13,34)?24. Su método exegético, fundamentado en considerar la Escritura como una unidad, no obstante los distintos autores humanos, le conducía a ello.

Esa identificación de la ley de Cristo con la ley del amor respondía a diversos intereses, según las épocas. En la primera, en polémica antimaniquea, le servía para manifestar el acuerdo entre el Antiguo y el Nuevo Testamento; más en concreto, para mostrar que también el Antiguo es ley de Cristo. Si la ley de Cristo ordena el amor al prójimo y el Antiguo ordena asimismo maxime el amor al prójimo, no puede ponerse en duda ${ }^{25}$. Con todo, Antiguo y Nuevo Testamento corresponden a diversas economías, con sus respectivos dones. Al respecto, $\mathrm{Ga}$ 6,2 se convierte en la prueba más diáfana de que la caridad es el don de la nueva, puesto que la antigua estaba dominada por el temor. Estas son sus palabras: «Como la observancia del Antiguo Testamento implicaba el temor, no se pudo señalar con mayor claridad que la gracia del Nuevo es la caridad que en el texto en el que el Apóstol dice: Llevad recíprocamente vuestras cargas y así cumpliréis la ley de Cristo» 26.

En el segundo período, sin embargo, dejará de lado esos aspectos relacionados con el conflicto con los maniqueos y lo arrastrarán otros, que tienen su origen en las tensas relaciones existentes entre católicos y donatistas. De la identidad establecida entre el mandatum de Jn 13,34-35 y la lex de Ga 6,2, deriva la importancia para el cristiano del precepto apostólico; de ella deduce también que los donatistas están alejados de la auténtica condición de cristianos. Aunque no lo afirme explícitamente, es lo que pretende que se sobreentienda en muchos textos en que interpreta el versillo en clave antidonatista. Puestas determinadas premisas, la conclusión no se hace esperar. En este caso las premisas eran estas: a) Lo que distingue al cristiano es el amor recíproco (cf. Jn 13,34-35); b) este amor recíproco se identifica con el recíproco llevar las cargas (Ga 6,2); c) como los donatistas no aceptan llevar las cargas de los demás, puesto que se han separado, no pueden ser considerados como cristianos. A juzgar por las obras donde lo propone, se dirige más a los católicos, que a los mismos donatistas. En los textos antidonatistas que nos ha conservado la producción agustiniana, los cismáticos nunca mencionan este texto. No sabemos si el no recurrir a él es pura circunstancia sin intencionalidad, o si lo evitaban porque se sentían indefensos ante él27.

24. RepPar 3,2,5; $\operatorname{TrCaJn} 1,12$.

25. $\operatorname{Exp} G a 58$.

26. $83 D Q 71,1$

27. Sólo cabe en Réplica al gramático Cresconio, no en RepPet y RepPar, porque escribieron antes de que san Agustín utilizase dicho texto paulino en clave antidonatista. 
En este contexto hay que añadir todavía que en La Trinidad asocia Ga 6,2 con $\mathrm{Ga} 5,14$ y $\mathrm{Mt} 7,12$, textos que recomiendan exclusivamente el amor del prójimo. Pero, además de establecer la identidad entre la ley de Cristo y la ley del amor, el santo se complace en ponderarla. Al llevar los unos las cargas de los otros no se cumple, dice, un precepto entre otros de los muchos dados por el Señor, sino su Ley por antonomasia, que en otro texto denomina «la sacratísima ley de la caridad»28. Caridad que, obviamente, lejos de ser algo sin importancia, constituye la cima y el objetivo último de todo el obrar de los cristianos. Como señala en un texto, tras citar $\mathrm{Ga}$ 6,2, en ella alcanza el cristiano su perfección: «Ella constituye la meta; por ella corremos, hacia ella corremos, en ella hallaremos el descanso cuando lleguemos» ${ }^{29}$.

Como complemento, no como alternativa a la anterior, el santo establece todavía otra identificación de la ley de Cristo. En un texto, la identifica primero con el amor y luego con la paz, recurriendo a Jn 14,27 y Ef 4,2-3. En el trasfondo se halla la controversia con los donatistas y la necesidad de lograr la paz eclesial. Replicando al cismático Parmeniano, después de citar Ga 6,12, escribe: «¿Cuál es la ley de Cristo, sino Os doy un mandato nuevo: que os améis los unos a los otros (Jn 13,34)? ¿Cuál es la ley de Cristo, sino Mi paz os doy, mi paz os dejo (Jn 14,27)?». El amor y la paz: dos conceptos que se hallan unidos en Ef 4,2-3, de que el obispo se sirve a continuación para explicitar $\mathrm{Ga}$ 6,2: «Lo mismo que dijo con las palabras: Llevad recíprocamente vuestras cargas y así cumpliréis la ley de Cristo, lo dijo en otro pasaje con estas otras: Soportándoos recíprocamente por amor, procurando guardar la unidad del espíritu en el vínculo de la paz»30.

La misma asociación entre Ga 6,2 y Ef 4,2-3 aparece también en RepPet y en los TrCaJn. Es significativa la danza de textos que organiza en el último pasaje mencionado. El punto de partida es el comentario a 1 Jn 2,10 (Quien ama al hermano permanece en la luz y no sufre escándalo). Llevado por el procedimiento de asociar términos o ideas, recurre a 2 Cor 11,29, Sal 120,6 y luego a Sal 118,65: Grande es la paz para los que aman tu ley, y no sufren escándalo. Mientras san Juan vincula el no sufrir escándalo al amor fraterno, el salmista lo vincula al cumplimiento de la ley de Dios. A quien pudiera ver una contradicción entre uno y otro texto, el predicador le replica que dicha ley no es otra que el precepto del amor fraterno y para confirmarlo cita Jn 13,34. Por tanto, no sufren escándalo los que se aman recíprocamente. Pero este amor tiene su manifestación en el soportarse mutuamente los hermanos.

28. Sermón 163 B,2.

29. $\operatorname{Tr} C a J n 10,4$.

30. RepPar 3,2,5. 
Como prueba aduce Ef 4,2-3 que explicita la paz de que hablaba el texto del salmo. Por último concluye: «Que esta es la ley de Cristo, escúchalo de boca del apóstol Pablo que recomienda esa misma ley: Llevad mutuamente vuestras cargas y así cumpliréis la ley de Cristo (Ga 6,2)». La conexión la establece identificando el soportarse de Ef 4,2 con el llevar mutuamente las cargas de Ga 6,2.

En pocas palabras: no sufren escándalo los que aman la ley de Dios (Sal 118,165); aman la ley de Dios los que aman a los hermanos (Jn 13,34); amar a los hermanos equivale a soportarlos y estar en paz con ellos (Ef 4,2-3); esto se identifica con la ley de Cristo (Ga 6,2). De esta manera, ha unido ley de Cristo y paz. Y, como señala A.-M. La Bonnardière, «el encadenamiento de los versillos Ga 6,1.2, Jn 13,34 y Ef 4,2-3 permite a san Agustín precisar el contenido del mandamiento de la caridad fraterna, poniendo de relieve lo que constituye a la vez su precio y su dificultad: la salvaguarda de la unidad y de la paz en el soportarse mutuamente»31.

\section{QUAE ONERA SINT ISTA}

Respecto a Ga 6,2, el mismo santo formula metodológicamente dos cuestiones: la primera, de qué cargas se trata (quae sint onera ista), y la segunda cómo se han de llevar (quemadmodum portanda sint) (Sermón 164,1,1). Comencemos por la primera; de la segunda nos ocuparemos en un apartado ulterior.

El término onus, onerare, onera (carga, cargar, cargas) aparece repetidamente en el Nuevo Testamento en relación con personas, tanto en sentido pasivo como activo. Dejando aparte Ga 6,5 (Cada uno llevará su propia carga) de que nos ocupamos aquí junto con $\mathrm{Ga} 6,2$, cabe mencionar $\mathrm{Mt}$ 11,28.30 (Venid a mi todos los que estáis fatigados y cargados [onerati], y yo os daré descanso... Porque mi yugo es suave y mi carga [onus/sarcina] ligera); Lc 11,46 (jAy de vosotros, leguleyos, que imponéis a los hombres cargas (oneratis... onera) intolerables, y vosotros no las tocáis ni con uno solo de vuestros dedos!). En 2 Co 11,9 el Apóstol señala que no fue gravoso (sine onere) a nadie; y en 1 Ts 2,9 habla de haber trabajado día y noche para no ser gravoso (oneri esse) a nadie; en $2 \mathrm{Tm} 3,6$ habla de quienes conquistan a mujerzuelas cargadas (oneratas) de pecados). En estos textos aparecen diferentes tipos de cargas: la que impone Cristo, es decir, su ley (Mt 11,30); las leyes humanas (Mt 11,28; Lc 11,46); la pobreza (2 Co 11,9; 1 Ts 2,9); los pecados (2 Tm 3,6).

31. Art. cit. p. 205. 
¿Qué tipo de carga es la que el obispo de Hipona ve aludida en Ga 6,2? Ya advertimos que resultaba sorprendente la poca fuerza de atracción que tenía el término onera de $\mathrm{Ga}$ 6,2 respecto de otros textos con el mismo término. Con todo, hay uno donde se establece la asociación y orienta el comentario de Ga 6,1-5.

El punto de partida es la contradicción que, a primera vista, parece existir entre los versillos segundo y quinto del capítulo sexto de la carta a los Gálatas. Mientras el primero ordena llevar recíprocamente las propias cargas, el segundo señala que cada cual llevará la suya propia. Tanto en el sermón 163 B como en el sermón 164 lo siente como un problema y lo propone como quaestio, la única que le plantea la perícopa de Ga 6,1-1032. La cuestión le ha ocupado en repetidas ocasiones, todas ellas dentro del período álgido de la controversia con los donatistas: La solución que ofrece el santo pasa por distinguir dos tipos de cargas.

En ConEv señala que en la Escritura hay términos que no tienen un significado unívoco, sino que, colocados coherentemente en distintos pasajes, han de entenderse de diferente manera. Entre los ejemplos que ofrece se hallan precisamente los versillos que nos ocupan. Escribe: «A veces la expresión es enigmática para ejercitar al investigador, como lo dicho a los gálatas: Llevad recíprocamente vuestras cargas... Pues cada cual llevará su propia carga (Ga 6,2.5). Si no se admite que "carga" tiene varios significados, inevitablemente se ha de pensar que el Apóstol se contradice al hablar -y esto en una misma sentencia en que las palabras están tan cercanas-... Pero una es la carga que consiste en ser partícipes de la debilidad del otro y otra la que consiste en dar cuenta a Dios de nuestros actos. La primera se comparte y se lleva con los hermanos; la segunda es propia y cada cual lleva la suya»33.

Esta distinción la establece de nuevo en el sermón 163 B, refiriéndola al pecado. A la debilidad que supone -de ahí la necesidad de la ayuda- hay que añadirle su significado desde el punto de vista de la piedad o relación con Dios, es decir, la responsabilidad moral, que no puede compartir con nadie ${ }^{34}$. Lo mismo expone en el sermón 164: hay cargas que cada cual ha de llevar por sí mismo, que nadie puede compartir con otro ni puede echar sobre las espaldas del hermano; y hay otras respecto de las cuales sí se puede decir: «La llevo contigo o la llevo por ti»35.

32. Sermón $163 \mathrm{~B}, 2 ; 164,1,2$.

33. ConEv 2,30,72.

34. Sermón $163 \mathrm{~B}, 2$.

35. Sermón $164,2,3$. 
Las cargas a que se refiere el Apóstol son, pues, ante todo, los pecados. «Las cargas que cada cual ha de llevar personalmente son los pecados»36. El significado de onus está determinado por Ga 6,1, que alude al hermano que ha sido sorprendido en alguna falta. Así, llevar recíprocamente las cargas significa «no desentenderse recíprocamente de los propios pecados»37. Por eso puede hablar de las cargas (sarcinas) perniciosas ${ }^{38}$ o malas ${ }^{39}$.

Estas cargas -los pecados- son múltiples y variadas ${ }^{40}$. En dos textos de la época del presbiterado nos ha dejado algunos ejemplos de cargas que el cristiano debe ayudar a llevar a los otros: no poder reprimir la complacencia ante la lisonja que a uno le tributan ${ }^{41}$, la ira y la locuacidad, la obstinación; más en general, la aegritudo o infirmitas, es decir, toda enfermedad o debilidad del alma ${ }^{42}$ o del cuerpo y del alma ${ }^{43}$. Sin embargo, en la época en que era más intensa la lucha antidonatista, introduce novedades significativas. En el citado sermón 164, en que se ocupa más detenidamente del asunto, el predicador nos ofrece un elenco, puramente ocasional, pero revelador. Allí distingue dos clases de cargas, unas que podemos llamar ordinarias y otras a las que él llama más pesadas (maiores). Como ejemplo de las primeras pone la carga de la avaricia (onus avaritiae) y la de la pereza (onus pigritiae) 44 ; las más pesadas son las que advierte sobre las espaldas de los donatistas: la carga de la división, escisión, cisma, herejía, disensión, odio, falsos testimonios y calumnias criminales $^{45}$. Es decir, los pecados contra la unidad de la Iglesia, ya en sus efectos, ya en sus causas. En el mismo contexto antidonatista considera como cargas las serias discrepancias acerca del bautismo de los herejes ${ }^{46}$.

Un texto citado anteriormente incluía entre las cargas las debilidades del cuerpo. El santo no limita, pues, a las deficiencias morales el campo de aplicación de $\mathrm{Ga} 6,247$. Él entiende que ha de extenderse a las restantes deficiencias de los hermanos, tanto las de orden intelectual como las de orden físico. En un sermón incluye entre ellas la carencia de ciencia, de consejo, o la pri-

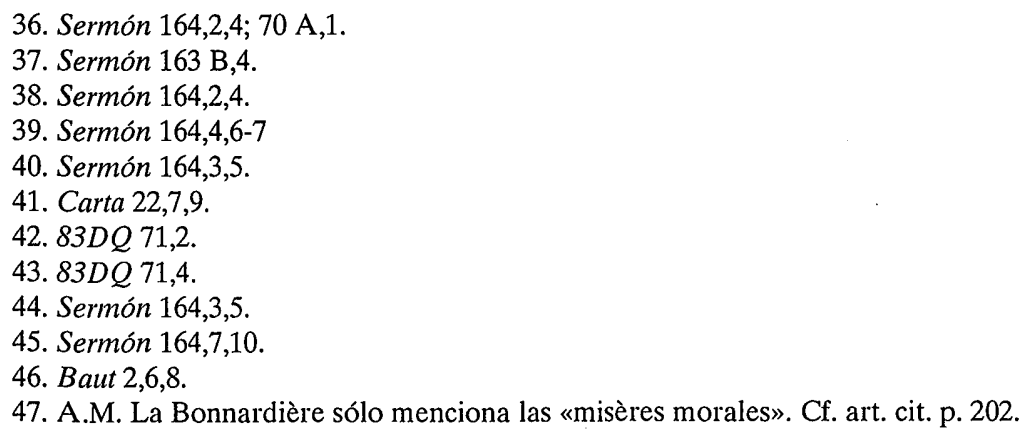


vación de algún sentido, o el padecer cualquier enfermedad48. En un par de textos añade otras dos: la pobreza y la riqueza ${ }^{49}$.

Hay, pues, cargas inherentes al hombre y cargas exteriores a su propio ser. Inherente al hombre es su propio pecado, su propia ignorancia en cualquier ámbito, sus propias deficiencias sensoriales u orgánicas; exterior al hombre es su propia pobreza o, incluso, su riqueza. Todas ellas son cargas cuyo peso ha de ser compartido. Pero, aunque el santo mencione ocasionalmente estas otras cargas, la principal de todas es evidentemente el pecado.

A propósito del pecado es preciso volver a los dos aspectos ya mencionados: como responsabilidad ante Dios -siempre personal-y como debilidad -compartible por los demás-, a que se refieren respectivamente Ga 6,5 y 6,2. Puede sorprender el hincapié que hace el santo en la mencionada distinción. Obedece, sin duda, al deseo de eliminar una contradicción entre dos textos de la Escritura, del mismo autor, en el mismo escrito y a tres versillos de distancia. Resulta claro del texto citado de ConEv. Y lo repite en el sermón 164: «Es preciso distinguir para que no parezca que se contradice el Apóstol»50. Pero obedece también a una razón menos teórica y más existencial; se ancla perfectamente en la controversia entre donatistas y católicos. Lo señala el santo con estas palabras: «Pensando en quienes creían que el hombre se puede contaminar con los pecados ajenos, dice el Apóstol: Cada uno cargará con su propio pecado. Y pensando en aquellos a quienes, en razón de lo anterior, se les infiltrase el desinterés por los demás y se creyesen seguros porque los pecados ajenos no le tocaban a ellos, dijo: Llevad recíprocamente los unos las cargas de los otros»51. En ellos hay que ver sin duda a los donatistas. Es conocido que admitían la teoría del contagio casi por la simple presencia física. En la conferencia de Cartago ni siquiera querían sentarse en una mesa común con los católicos para no contaminarse con su presunto pecado de traditio. Por esa misma razón rehusaban la comunión con ellos. El cisma apareció cuando unos obispos númidas acusaron a Ceciliano de dejarse ordenar por unos traditores, porque consideraban que se hacían partícipes de su pecado de traditio. Los sacramentos conferidos por ministros pecadores los juzgaban inválidos entre otras razones porque, en su opinión, el recibirlos implicaba comulgar en el pecado del ministro. La posición de los donatistas la expresa al alertar a sus fieles para que no se dejen engañar por quienes dicen: «Nosotros somos santos, renunciamos a llevar vuestras cargas y, por lo tanto,

48. Sermón $91,7,9$.

49. Sermón 164,7,9; 91,7,9.

50. Sermón 164,1,2.

51. Sermón 164,2,3. 
no mantenemos la comunión con vosotros» 52 . Es decir, renunciaban a cumplir Ga 6,2 por no tener en cuenta $\mathrm{Ga} 6,5$ o por interpretarlo mal, al creer que producían contagio. En el mismo sermón 164 introduce un diálogo ficticio con un donatista. El predicador ha citado Ga 6,2 y el donatista le responde: «Pero yo no comulgo con los pecados ajenos». A ello replica el predicador: «Como si yo te estuviera diciendo: "Ven, participa de los pecados de los otros". No es eso lo que te digo; sé muy bien lo que indicó el Apóstol, y eso es lo que afirmo yo. No debías haber desertado de la grey de Dios, constituida a la vez por ovejas y cabritos, por motivo de los pecados ajenos, aunque fuesen verdaderos o no fuesen más bien tuyos...». Sigue la posterior réplica del donatista: «Y ¿cómo voy a soportar a quien sé que es malo?», y la contrarréplica del predicador: «¿No te es mejor soportarle a él que excluirte a ti mismo? Mira cómo has de soportarlo; basta con que prestes atención al Apóstol cuando dice que cada uno llevará su propia carga. Esta sentencia te libera de toda responsabilidad (en el pecado ajeno)»53. Según el predicador, los donatistas, al entender de forma unívoca el onus de que habla del apóstol, no hallaban forma de acercarse a las cargas de los demás, porque creían que implicaba comulgar en su pecado. El llevar (portare) lo interpretaban como «comulgar con».

A esa tesis donatista san Agustín responde con la distinción ya señalada. En lo que tiene de responsabilidad moral, del pecado sólo ha de responder el pecador. Su propia posición doctrinal queda sintetizada en estas palabras de un sermón: «Hay que mantener como definido, fijo e inmutable, y ello con toda certeza, que ningún bueno será bueno en lugar de otro y ningún malo será malo en lugar de otro» ${ }^{54}$, afirmación que sostiene con la cita de $\mathrm{Ga} 6,5$, a la que añade Rom 14,12 y Ga 6,4. O también de esta otra manera: «Quien viva santamente en la Iglesia, no sufre daño alguno por pecados ajenos, porque en ella cada uno llevará su propia carga... pues nadie se mancha por comulgar con los malos cuando participa de los sacramentos, sino cuando consiente en sus obras. Si uno no consiente en esas obras malas, el malo llevará su causa... pero no sienta prejuicio contra aquel que no fue su compañero de crimen por no haber consentido en su mal»55. Como apoyo bíblico, aquí añade 1 Co 11,29 a Ga 6,5. La consecuencia es que, cuando uno, por caridad, ayuda a llevar a los hermanos sus cargas, no ha de temer que estas le aplasten, es decir, no ha de temer cargar con la responsabilidad de los pecados ajenos. Sólo ha de preocuparse de que no le opriman las propias, el propio peca-

52. Sermón $164,7,10$.

53. Sermón $164,7,11$.

54. Sermón 35,2.

55. Carta 141,5. 
do. Los del prójimo sólo le oprimirán en el caso de que consienta a ellos. Pero en ese caso, lo que le oprime no es el pecado del otro, sino el propio, el que personalmente ha cometido al asentir a él.

Aduce como ejemplo el caso mencionado en el versillo 18 del salmo 49: Una persona divisó a un ladrón y corrió a sumársele. Por el hecho de correr a unírsele o, mejor, por habérsele asociado en el deseo, lo que era pecado sólo del otro, se convirtió también en pecado suyo; y se convirtió en pecado suyo por el simple hecho de que le agradó la acción. Si, en cambio, sintió desagrado ante ella, en ningún modo echa sobre sus espaldas algún otro pecado56. El apóstol ha distinguido bien entre carga y carga, entre la que cada cual debe llevar personalmente, y la que debe llevar con los demás. Ante Dios cada cual tiene su propia causa, su propia carga. Y una más entre otras puede ser precisamente la que proviene de no haber cumplido con Ga 6,2, la de no haber querido llevar la del hermano. Así lo afirma expresamente de los dirigentes (praepositi): «Los mismos dirigentes que han de dar cuenta del rebaño de Cristo a ellos confiado, rendirán cuentas de su pecado, si se desentienden de las ovejas del rebaño de Cristo»57.

En lo que tiene de debilidad, sin embargo, se constituye en carga a compartir. Al respecto, la solidaridad no sólo cabe, sino que es exigida por el Apóstol y, en última instancia, por el Señor. Sobre los modos concretos cómo ejercer esa solidaridad hablaremos más adelante.

El santo tiene todavía otra manera de expresarse. En RepPet distingue entre la carga del tener que rendir cuentas ante Dios y las cargas de la caridad recíproca58. Al utilizar el plural, no parece que haya que identificar las cargas con la caridad recíproca. Habla de cargas de la caridad recíproca porque es esa caridad la única que es capaz de llevarlas. Sin embargo, es preciso traer aquí el sermón 164 en que el santo considera sin más la caridad como una carga (onus, sarcina). Pero señala que es una carga con características especiales que la distinguen de las otras consideradas anteriormente. Hay cargas que oprimen y cargas que liberan y elevan. Las apetencias mundanas (cupiditas) pertenecen a las primeras, la caridad a las segundas. Si el hombre está bajo el peso de la primera, es para su mal; si está bajo el de la segunda, es para su bien, para su salvación. Oprimen y dañan las apetencias mundanas; libera, eleva y aporta salvación la caridad 59 . No halla mejor comparación que la establecida con las alas de un ave. Ciertamente representan un peso para ella, pero gracias a ese peso puede levantarse y volar. «En efecto, las aves lle-

56. ComSal 129,4.

57. Sermón 163 B,2.

58. RepPet 3,5,6.

59. Sermón $164,4,6$. 
van el peso de sus alas. Lo llevan en tierra y son llevadas por él en el aire: Si queriendo mostrarte misericordioso con el ave, sobre todo en verano, y diciendo: "esta desdichada avecilla arrastra el peso de sus alas" se lo quitas, se arrastrará por tierra aquella a la que quisiste ayudar. Carga pues, con las plumas de la paz; recibe las alas de la caridad. Esta es la carga (sarcina) y así cumplirás la ley de Cristo» 60 .

Ambas cargas son inconciliables; no pueden existir simultáneamente en una misma persona. La aparición de una implica la desaparición de la otra: «Cuando el Señor sacudió de tus hombros una carga, te impuso otra; sacudió la de las apetencias mundanas y te impuso la de la caridad. Así, pues, respecto de las malas apetencias cada cual lleva su carga: el malo, la mala; el bueno, la buena»61. Es decir, el malo, la carga oprimente de su apetencia; el bueno, la carga liberadora de la caridad. La misma carga (las apetencias mundanas) la han de llevar los dos, pero de distinta manera: uno como responsabilidad propia y otro como campo de ejercicio de la caridad. Así, pues, la caridad en su condición de carga, se distingue de las demás por su origen, por su características y por su eficacia. Por su origen, porque es Cristo quien la impone; es la carga de Cristo (sarcina Christi), en cuanto precepto impuesto por él62; por sus características, porque no oprime, sino que eleva; por su fuerza, porque permite llevar con los demás la propia carga (unde portes cum altero onus proprium) ${ }^{63}$. Es la caridad la que lleva las cargas. Con otra imagen, es la caridad la que hace de balsa que impide que el hombre se hunda en el abismo con su carga en la travesía del mar de esta vida64.

Concluyendo, de los textos agustinianos resultan tres clases diferentes de cargas: la primera, el pecado en cuanto responsabilidad ante Dios; es una carga que oprime. La segunda, el mismo pecado en cuanto debilidad y flaqueza que necesitan ser ayudadas, toda carencia de cualquier bien material o espiritual o, incluso, el exceso de bienes materiales; carga que también oprime. La tercera, la caridad, carga que, en vez de oprimir, libera y, en lugar de dañar, sana. Carga totalmente ajena a la primera y que capacita para llevar recíprocamente la segunda. En Ga 6,5 el Apóstol tenía en mente sólo la primera, en $\mathrm{Ga}$ 6,2 la segunda.

60. Sermón $164,5,7$

61. Sermón 164,6,8.

62. Sermón 164,7,9.

63. Sermón 164,7,9.

64. ComSal 129,4. 


\section{FUNDAMENTOS}

Los cristianos han de llevar los unos las cargas de los otros porque así lo ordena el Apóstol y, a través de él, Cristo. En la primera mención que hace el santo de Ga 6,2 presenta explícitamente el precepto como precepto de Cristo: «Quien nos dio el precepto»65. Y en otro texto temprano: «Esta es la ley de Cristo: que llevemos mutuamente nuestras cargas»66. Detrás de la autoridad del Apóstol, está la de Cristo. El cristiano, pues, no hallará forma de eximirse del cumplimiento del precepto del Ga 6,2.

Mas, para estimular su cumplimiento, el santo aporta otros argumentos, ninguno de ellos apuntado por el apóstol en su texto. El tratamiento más completo corresponde a los primeros años de su ministerio, cuando aún era presbítero. Nos estamos refiriendo a la obra $83 D Q$. Como ya se indicó, una de las cuestiones, la 71, la dedica enteramente a la exposición de Ga 6,2. Su comentario señala brevemente que la ley de Cristo a que se refiere el Apóstol es la ley del amor, como aparece formulada en Jn 13,34-35; que esa caridad implica como exigencia o deber el llevar recíprocamente los unos las cargas de los otros; que ese deber es transitorio, hasta que se llegue a la felicidad eterna, donde ya no habrá cargas ajenas que llevar; que determinado comportamiento que se atribuye a los ciervos puede hacer entender mejor en qué consiste llevar las cargas; las condiciones y objetivo que se pretende ${ }^{67}$. De esto más adelante.

En un segundo momento, de forma indirecta, apunta que las «cargas» son las «debilidades» de unos y otros e indica cuándo es posible el cumplimiento del precepto: podrán llevar los unos las cargas de los otros, sólo si éstas son distintas o, en el caso de que sean las mismas, no son simultáneas. Como ejemplo de este último caso aduce el de dos personas respecto de la ira: si las dos están airadas, mal puede una llevar la debilidad de la otra. Pero si lo está una y no la otra, la que no lo está puede «llevar» la ira de la otra no airándose contra ella, aunque en otro momento se vuelvan los papeles, cuando la antes airada tenga que tolerar, con su mansedumbre y suavidad, la ira de quien antes la soportó a ella. Si la ira es recíproca y simultánea, está claro que no se pueden «tolerar» recíprocamente; sí, en cambio, si la ira de una y otra persona va dirigida contra una tercera. Pero luego corrige la expresión: en realidad, más que tolerarse, se consuelan mutuamente. Distinto es el caso -sigue diciendo-, cuando uno ha vencido la locuacidad, pero no la obstina-

65. Carta $22,7,9$.

66. $83 D Q 71,7$

67. $83 D Q 71,1$. 
ción y otro ya no obstinado, pero es un charlatán. Entonces uno ha de soportar la obstinación del otro y éste la locuacidad de aquél, hasta que ambos queden sanados.

Después de estas observaciones se detiene en lo que más le interesa: dar argumentos para estimular al cumplimiento de dicho precepto apostólico. Tres son los que aduce aquí. El primero de ellos, el ejemplo de Cristo; los otros dos hacen referencia a la condición humana de una forma genérica. Pero no son los únicos ofrecidos por el santo. Veámoslos uno a uno.

\section{a. El supremo ejemplo de Cristo}

En efecto, dice, nada hay que haga que uno se entregue a cumplir este deber fatigoso de llevar las cargar de los otros de buen grado como pensar en cuánto padeció por nosotros el Señor. Para confirmarlo aduce Flp 2,5-8, que muestra cómo el Señor cumplió lo que ordena el Apóstol en el v. 4 del mismo capítulo: Buscando cada cual no su propio interés, sino el de los demás. En efecto, él, aunque carecía de pecado, al encarnarse y habitar entre nosotros, tomó los nuestros y no miró por lo suyo, sino por lo nuestro; de idéntica manera, también nosotros, a imitación suya, hemos de llevar recíprocamente y de buen grado nuestras cargas ${ }^{68}$. El llevar recíprocamente las cargas ha de surgir espontáneamente, pues, del amor a Cristo. Amándole a él, resulta fácil soportar (sustinere) la debilidad del otro, incluso la de aquel a quien no se ama por determinados bienes, puesto que no se han descubierto en él. Basta con pensar que el Señor murió por aquel a quien amamos. A ese amor se refiere el apóstol Pablo al decir: ; Y a causa de tu ciencia va a perecer un hermano por el que murió Cristo! (1 Co 8,11). El santo da la receta: Si se ama menos a determinada persona por un vicio que la tiene enferma, se ha de considerar quién ha muerto por ella. No amar a Cristo no es una debilidad, sino la muerte misma. Con sumo cuidado e implorando la misericordia de Dios hay que guardarse de despreciar a Cristo a causa de un débil, siendo así que debemos amar al débil por Cristo69.

El recurso al ejemplo de Cristo, sin embargo, aparece ya antes, en la primera referencia que le conocemos a este texto apostólico. El entonces presbítero suplica a su amigo, el obispo de Cartago Aurelio, que, a la vista de sus debilidades, ruegue insistentemente por él a Dios. Y se lo suplica «por la humanidad de quien nos dio el precepto de llevar mutuamente los unos las 
cargas de los otros»70. La mención de la humanidad de Cristo tiene la función de poner su encarnación como ejemplo a Aurelio. Igual que Cristo fue capaz de hacerse hombre para cargar sobre sí con las enfermedades de los hombres, así Aurelio ha de hacerlo también cargando con las debilidades del mismo Agustín. ¿De qué manera? Orando por él. Como se verá, la oración es una de las formas de llevar recíprocamente las cargas.

En la RepPar combina 1 Co 5,6-7, Ga 6,1-2 y Lc 18,10-14. En el fariseo de la parábola lucana -refiere- parecía hallarse la poca levadura que corrompe toda la masa, puesto que no sólo no sentía dolor por el publicano, sino que se apoyaba en él para exaltar sus méritos. Pero, como el que se humilla será exaltado y el que se exalta será humillado, el publicano salió más justificado que el fariseo. La sentencia del Señor indica la capacidad de conversión. Esa misma capacidad la señala también este otro texto del Apóstol: despojaos de la levadura vieja para ser masa nueva, como sois ácimos. Según él, había quienes eran ya panes ácimos y quienes aún no lo eran; por tanto, los que lo eran no debían perder la esperanza respecto de quienes no lo eran aún, razón por la que amonesta: para que lleguéis a serlo. Con esa advertencia del Apóstol -añade el obispo- los ya purificados debían aprender a soportar a quienes todavía no lo estaban, con el fin de conservar la unidad que otorga el Espíritu con el vínculo de la paz (Ef 4,2-3), mediante la mutua tolerancia en el amor y, llevando los unos las cargas de los otros, cumplir efectivamente la ley de Cristo $(\mathrm{Ga}$ 6,2). A continuación el santo recurre al ejemplo de Cristo que, para enseñarnos el camino de la humildad, se dignó rebajarse hasta la muerte de cruz y, como el médico soporta a los enfermos, así el soportó a los pecadores, de quienes había dicho: No necesitan del médico los enfermos, sino los pecadores (Mt 9,12). Es la misma razón por la que Pablo puso el ejemplo supremo (principale): Porque Cristo, nuestro cordero pascual ya fue inmolado (1 Co 5,7). Así, con el ejemplo de tanta humildad, aprenderían a eliminar la vieja levadura -en este caso, el no querer llevar las cargas de los demás- en vez de aprovecharse de ellas para ensalzarse más, como había hecho el fariseo de la parábola. De nuevo, el ejemplo de Cristo aparece como estímulo supremo para el cumplimiento del doble precepto apostólico (Ga 6,2 y Ef 4,2-3)71.

El ejemplo de Cristo aparece otra vez en el sermón 163 B. Dice allí: «Si toleras tú lo que no puede tolerar tu hermano y él lo que no puedes tolerar tú, lleváis recíprocamente vuestras cargas, y comportándoos así cumplís la sacratísima ley de la caridad. Ella es la ley de Cristo. Él vino porque nos amó y aunque no había qué amar, amándonos nos hizo dignos de amor. Así habéis

70. Carta 22,2,9.

71. RepPar 3,2,5. 
oído qué significa: Llevad recíprocamente vuestras cargas y así cumpliréis la ley de Cristo»72.

\section{b. El desconocimiento de sí}

El segundo argumento se apoya en el desconocimiento, al menos parcial, que todo hombre tiene de sí mismo. Ello debe llevarle a considerar que cualquier enfermedad, del cuerpo o del alma, que vea en el prójimo ha podido o puede tenerla él. A partir de ahí es coherente ofrecer al que sufre una enfermedad la misma ayuda que quisiera que a él le prestase en el caso de que el sano fuese el otro y el enfermo él. El ejemplo bíblico de esta postura se lo ofrece san Pablo, que afirma haberse hecho todo para con todos para ganarlos a todos (1 Co 9,22), al pensar que él mismo pudo haberse hallado en el mismo vicio del que deseaba liberar al otro ${ }^{73}$. El doble convencimiento de que nada inclina tanto a la misericordia como el pensar en el peligro en que uno se halla y de que la paz y el amor se preservan considerando el común peligro (cf. ExpGa 56) inspira este argumento.

\section{c. El desconocimiento del prójimo}

Si es difícil conocerse uno a sí mismo, más difícil es conocer al prójimo. El santo recurre también a esa consideración para motivar el cumplimiento del precepto apostólico. ¿Cómo? Pensando en la bondad del prójimo, quizá desconocida para uno; es decir, considerando que no hay hombre que no pueda tener algún bien del que uno mismo carece, aunque ignore que el otro lo tiene y, en virtud del cual, el prójimo puede ser superior a uno mismo. Tal consideración, dice, es capaz de machacar y domar la soberbia. Eso se hace realidad, si se piensa que el hecho de que descuellen y salten a la vista las propias cualidades no significa que el prójimo carezca de ellas, y que puede darse, incluso, que sus bondades sean superiores a las propias, sólo que son desconocidas. Puede darse también el caso de que el propio bien, inferior, sea manifiesto, y el del otro, superior, quede oculto. El apoyo bíblico lo encuentra de nuevo en el apóstol Pablo quien, no para engañar ni por afán de adulación, propone no hacer nada por rivalidad ni por vanagloria, sino estimar a

72. Sermón 163 B,2. San Agustín recurre todavía al ejemplo de Cristo en RepPar 3,2,5. Cf. más adelante, apartado d.

73. $83 D Q 71,4$. 
los demás como superiores a uno mismo (Flp 2,3). Estimación que debe ser real, no fingida. También este tipo de reflexiones abaten la soberbia, estimulan la caridad y hacen que se lleven mutuamente las cargas, no sólo con ánimo sereno, sino hasta con sumo agrado ${ }^{74}$. Para poner término a la reflexión, introduce una afirmación de alcance general: nunca se ha de proferir sentencia alguna contra cualquier hombre al que se desconozca. Ahora bien, a nadie se le conoce sino es por la amistad. De ahí que se aguanten con mayor fortaleza los males de los amigos, por el motivo de que conocemos sus bienes que nos agradan y nos cautivan 75 .

No es el indicado el único texto en que el obispo hace referencia a ese desconocimiento del prójimo en el contexto de Ga 6,2. En un sermón dice: «Porque te haya ofendido no sé quién, ya sea realmente malvado, ya lo sea sólo en tu mente o en tu imaginación, ¿ya vas a abandonar a tantos buenos?»76. El texto alude a los donatistas que rompen la unidad (Ef 4,2-3), al no querer llevar las cargas (el pecado) de los demás (Ga 6,2). El predicador quiere mostrar que la rotura de la unidad no tiene otra causa que el no querer llevar cargas que pueden ser reales, pero que a veces son sólo creaciones de la propia imaginación o, incluso, de la propia mala voluntad. Un conocimiento más objetivo del prójimo haría posible otro tipo de comportamiento.

\section{d. Memoria del propio pasado}

En $83 D Q$ hacía hincapié en que el hombre no conoce al hombre, ni a sí ni al prójimo y, por tanto, puede equivocarse respecto de él. Pero, aunque no se conozca plenamente, no se desconoce del todo. Hay datos sobre los que nadie con criterio abriga duda alguna. Una de las certezas que, respecto de sí mismo, tiene el cristiano se refiere a su antigua condición de esclavo del pecado. A ese conocimiento se agarra el santo para reclamar un comportamiento conforme al precepto apostólico. En un pasaje de la RepPar une en un mismo argumento el ejemplo de Cristo y la propia condición pasada. De ella no se libró personalmente el cristiano, sino que le libraron. El conocimiento de ese dato debe impulsarle -piensa el pastor-a tender la mano a quienes en el presente se hallan caídos. Escribe: «Es malicia y malignidad gloriarse del pecado ajeno, como si cada cual debiera gozar de su justicia precisamente cuando haya advertido que otro no es justo. Lo auténtico y lo verdadero es esto: aun

74. $83 D Q 7,5$.

75. $83 D Q 71,5$.

76. TrCaJn 1,12 . 
en el caso de que alguien haya progresado en la virtud, debe acordarse de su pasado para acrecentar su misericordia hacia quienes han caído, pues también él mismo ha sido levantado de su caída por la misericordia de Cristo, quien se humilló por los pecadores a pesar de no tener él pecado alguno» ${ }^{77}$.

El texto que acabamos de citar se dirigía al cristiano que ha hecho progresos en su vida espiritual. Para estimularse a llevar las cargas de los otros, el obispo le sugiere mirar no a su salud presente, sino a su enfermedad anterior; no al punto de llegada, sino al de partida. En los $\operatorname{Tr} E v J n$ vuelve sobre la idea. Comenta la orden de Jesús al paralítico curado de tomar su camilla y ponerse en marcha. En la camilla ve simbolizado al hermano que le llevaba (soportaba sus debilidades) y al que ahora, invertida la situación, debe llevar él, ya sano. El santo comenta: «¿Por qué se ha de ver en la camilla al prójimo? Porque cuando estaba enfermo era llevado en ella, mientras que una vez sano ya lleva él la camilla. ¿Qué dijo el Apóstol? Llevad recíprocamente vuestras cargas y así cumpliréis la ley de Cristo. La ley de Cristo es la caridad y la caridad no se hace realidad si no llevamos recíprocamente nuestras cargas. Soportaos los unos a los otros mutuamente con caridad afanándoos por conservar la unidad del espíritu en el vínculo de la paz (Ef 4,2-3). Cuando el enfermo eras tú, te llevaba tu prójimo a ti; ahora que estás ya sano, lleva tú a tu prójimo. Llevad recíprocamente vuestras cargas y así cumpliréis la ley de Cristo. Así cumplirás, oh hombre, lo que te faltaba: camina»78. Todo consiste en que aprenda a llevar a quien antes le llevaba a él79. A la consideración del propio pasado, negativo, pero afortunadamente superado, recurre también exponiendo el salmo 99, en un contexto idéntico: el de quien quiere abandonar la compañía de los que cree menos perfectos que él para no tener que soportarlos. Aunque aquí no aparezca explícitamente Ga 6,2 no importa porque trata de la misma temática. Dice así: «Quieres segregarte de los demás para que nadie te vea y te moleste. ¿A quién aprovechas? ¿Hubieras llegado tú a ese nivel de perfección si nadie te hubiese ayudado? ¿Acaso porque te parece haber tenido pies más veloces para pasar has de cortar el puente?»80.

\section{e. Pensar en el propio futuro}

Si la consideración del propio pasado debe ayudar a llevar las cargas de los demás, no menos debe ayudar el pensar en el futuro. El mismo capítulo sexto

77. RepPar 3,2,5.

78. TrEvJn 17,9.

79. $\operatorname{Tr} E v J n$ 17,11: si didicisti portare, qui solebas portari.

80. ComSal 99,9. 
de la carta a los Gálatas favorece esta reflexión. Después de exhortar al «espiritual» a corregir al hermano sorprendido en alguna falta, Ga 6,1 le invita a la precaución no sea que también él sea tentado. Esta posibilidad de futuro, anclada en la misma condición humana, orienta también la reflexión del obispo.

Como ya se ha indicado, la exhortación de $\mathrm{Ga} 6,1$ va dirigida específicamente a los «espirituales», es decir, a aquellos cristianos que se hallan ya en un nivel superior de vida cristiana y no se dejan llevar por los impulsos «carnales». Precisamente la conciencia de esa condición de «espirituales» puede conducir a dos actitudes diferentes, ambas erráticas. Unos pueden creerse eximidos de llevar las cargas de los demás al considerarse sin carga propia que tengan que ayudarle a llevar los otros. Pensando en ellos, afirma el santo: «Y dado que dirigía la exhortación a los espirituales, para evitar que se sintiesen como seguros, añadió: mantente en guardia, no sea que también tú seas tentado. Y a continuación agregó lo ya citado: Llevad recíprocamente vuestras cargas y así cumpliréis la ley de Cristo»81. Otros, por el contrario, pueden aceptar llevar las cargas de los demás, pero desde una actitud interior de orgullo, reflejada en estas sus otras palabras: «Llevamos las cargas de quienes han incurrido en pecado, dado que nada hay en nosotros que ellos puedan llevar»: Este razonamiento destruye la lógica del invicem, del recíprocamente, de $\mathrm{Ga}$ 6,2. A unos y a otros baja del burro el obispo amparándose en la mencionada advertencia del Apóstol, cuya verdad fundamenta en la común condición humana: no olvides que eres hombre.

Exponiendo el salmo 129 afirma: «Los que carecen de caridad se resultan mutuamente gravosos; en cambio, quienes la poseen se llevan las cargas recíprocamente. Alguien te ha dañado y te pide perdón; si no le perdonas, no llevas la carga de tu hermano; si le perdonas, llevas al enfermo. Y tú si caes enfermo de algo, como hombre que eres, es preciso que te lleve también el otro, como tú le llevaste a él»82. Aquí el obispo advierte de la posibilidad, debida a la condición humana, que tiene todo cristiano de caer él también. Y un poco más adelante añade: «Aprendiste a llevar las cargas de tu hermano, para que también él lleve las tuyas, si es que las tienes, y se haga realidad en vosotros lo que dice el Apóstol: Llevad recíprocamente vuestras cargas $($ Ib. $) " 83$.

81. ComSal 129,4; Sermón 163 B,4.

82. ComSal 129,4.

83. En el comentario al salmo 129, impulsado, sin duda, por el texto que comenta: Desde lo hondo a ti grito, Señor... Si te fijas en los pecados, ¿quién podrá resistir? (Sal 129,1.3), señala que, aunque el hombre se vea libre de pecados graves como el adulterio y el homicidio entre otros, nadie está libre de los pecados al menos de pensamiento o de palabra, ante los cuales sólo encontrará a Dios propicio, si cumple su ley de llevar recíprocamente los unos las cargas de los demás (ComSal 129,5). 
En otro texto posterior advierte: «No te creas santo, si nadie te tienta. Lo eres, si no pierdes la paz ante una injuria, si sientes dolor por quien te ha ultrajado, si no te preocupas de lo que padeces, sino que te apiadas de aquel que te hace padecerlo... Se ensaña contra ti, está enfermo, es un frenético. Apiádate de él, no te alegres; alégrate únicamente en la tranquilidad de tu conciencia. Duélete por él. No olvides que eres un hombre; por tanto, estáte atento, no sea que también tú seas tentado (cf. Ga 6,1). Se ha dicho: LLevad recíprocamente vuestras cargas y así cumpliréis la ley de Cristo ( $\mathrm{Ga} 6,2) » 84$.

A quien se coloca en la actitud orgullosa antes mencionada, el obispo le invita primero a prestar atención a las palabras del Apóstol, según las cuales ha de mantenerse en guardia, no sea que también él sea tentado. Estas palabras, comenta, las dijo el Apóstol para que nadie se ensoberbeciera ni se envaneciera. Pero luego pregunta a ese cristiano «espiritual» si su condición de «espiritual» anula su condición de hombre; si por el hecho de ser «espiritual» ya no lleva el cuerpo mortal, lastre para el alma (Sb 9,5) o ha alcanzado ya el término de su vida, que es una tentación continua sobre la tierra $(\mathrm{Jb} 7,1)$. La respuesta, obviamente negativa, a la triple pregunta muestra, al parecer del predicador, cuán adecuadamente y con cuánta razón se le dijo: Con la mirada puesta en ti mismo, no sea que también tú seas tentado. De hecho, comenta, sólo después de haber hecho esa advertencia a los espirituales, introdujo la sentencia de alcance general: Llevad reciprocamente vuestras cargas y así cumpliréis la ley de Cristo. Por el hecho de que todo hombre es hombre y, por tanto, abierto a la posibilidad del pecado, todos han de llevar recíprocamente sus cargas 85 .

La advertencia que hace específicamente a los que progresan en la vida espiritual que hemos visto en la obra RepPar la encontramos de nuevo en CiudD. Según el santo, el precepto de Ga 6,2, junto con otros (cf. 1 Ts 5,14-15; Ef 4,26; Mt 18,35; $1 \mathrm{Tm} 5,20$ ), se dio para los buenos que progresan (proficientibus) y para los que en esta peregrinación viven de la fe, en atención a la debilidad de todo hombre, consecuencia de un vicio ${ }^{86}$. Ese vicio presente en la naturaleza hace que nadie, aunque haya hecho progresos en el bien, aunque esté en camino hacia la Jerusalén celeste, tenga asegurada la paz futura.

84. Sermón 16 A,7.

85. Sermón 163 B,4; Carta 219,1.

86. CiudD 15,6. 


\section{f. Considerar el propio presente}

La consideración del propio pasado y las posibilidades de signo negativo abiertas ante el futuro deben mover a llevar las cargas de los demás. A la misma conclusión ha de conducir la consideración del presente. El hombre no sólo fue pecador; no sólo puede volver a caer en pecado; también es pecador. Nadie está de hecho libre del pecado. Esta temática, más propia de la época de la controversia pelagiana, se halla presente también en la donatista, aunque desde otra perspectiva. El donatista ensalzaba la santidad de su Iglesia y se amparaba en ella para rechazar la comunión con los católicos y negaba la validez a los sacramentos administrados por ministros católicos por considerarlos pecadores ${ }^{87}$. Contra ellos, el santo argumenta que también los donatistas son pecadores, que todo hombre es pecador.

En el sermón 163 B,2 argumentaba con el ejemplo de Cristo; pero inmediatamente antes había argumentado también desde la condición humana. Había distinguido las dos clases de cargas que acompañan a todo pecado: en cuanto implican debilidad que pesa, los unos llevan las cargas de los otros; en cuanto responsabilidad moral, cada uno llevará la suya propia. Luego se preguntaba: «¿Qué acabo de decir? ¿Qué son los hombres, sino hombres, y por eso mismo seres débiles que no podemos estar sin pecado? En esto, pues, llevamos los unos las cargas de los otros»88. Todo hombre es débil, todo hombre es pecador; por ello, todo hombre necesita que le ayuden a llevar su carga de pecado y por ello también ha de estar dispuesto a ayudar a llevar la de los demás.

En el mismo sermón dice un poco más adelante: «Recordad: Si algún hombre ha sido sorprendido en alguna falta. No dijo "si fulano de tal", sino si un hombre. Es cosa muy difícil que un hombre no sea sorprendido en alguna falta, pues ¿qué es un hombre?»89. La afirmación del pecado en todo hombre no es tan rotunda como lo será más tarde en la polémica contra los pelagianos, pero es suficientemente clara, vinculando además el pecado a la simple condición humana. Más adelante volverá todavía a insistir en lo mismo: «Está claro que el apóstol ordenó: Llevad recíprocamente vuestras cargas, porque había amonestado al hombre "espiritual" y le había dicho: con la mirada puesta en ti mismo, no sea que también tú seas tentado, para que ese "espiritual" no se arrogase tanto mérito, hasta creer que carece de carga que requie-

87. Prescindimos de la clase de pecado a que hiciesen referencia los donatistas, puesto que san Agustín argumenta como si se tratase de toda clase de pecado.

88. Sermón 163 B,2.

89. Sermón $163 \mathrm{~B}, 3$.

90. Sermón $163 \mathrm{~B}, 4$. 
ra la ayuda de los demás para llevarla»90. Si en otros textos advertía al «espiritual» que no estaba exento de volver a caer en el pecado, aquí le recuerda que la condición de espiritual no le excluye de la condición de pecador. No ha de creer que carece de pecado que tengan que llevarle los demás.

El argumento aparece con idéntica claridad en el sermón 164. Después de describir la «enfermedad» de los donatistas, el predicador se dirige a sus fieles: «Soportadlos pacientemente si estáis sanos; soportadlos pacientemente en la medida en que estáis sanos. Pues ¿quién está totalmente sano? Cuando el rey justo se siente en su trono, ¿quién se gloriará de estar limpio de todo pecado? Por tanto, mientras nuestra condición sea esa, nuestro común deber es llevar mutuamente nuestras cargas»91. Primero pone la condición: si estáis sanos; pero luego limita su alcance, indicando que la salud completa no existe; la posesión de la salud es relativa. En consecuencia, quien tiene cargas que otros han de ayudarle a llevar, debe ayudar a llevar las suyas a los demás. El hecho, no ya de estar sano, que nadie lo está plenamente, sino de estar menos enfermo, o haber progresado algo, no debe impedir el llevar las cargas de los hermanos; más aún, sus mayores fuerzas se lo reclaman más vivamente. Aun admitiendo que siempre hay pecado, a menor pecado, menor enfermedad y a menor enfermedad, más fuerzas para llevar las cargas de los demás.

\section{g. Tener presente la teología del Cuerpo Místico}

La teología del Cuerpo Místico de Cristo ofrece un buen motivo para estimular el cumplimiento del precepto paulino. Pero causa cierta sorpresa el poco uso que san Agustín, el teólogo del Cuerpo Místico, hace de ella. Es significativo que entre los abundantes textos bíblicos que vimos hacer corte a $\mathrm{Ga}$ 6,2 no haya ninguno de los que el santo suele citar en apoyo de la teología del Cuerpo Místico. A lo más podría citarse a 1 Co 12,26 (Cuando sufre un miembro, sufren todos con él) que aparece en RepPar dentro de un razonamiento que acabará en la cita, a cierta distancia, de Ga 6,292. De hecho, en los textos en que comenta $\mathrm{Ga} 6,2$ sólo se advierte un breve apunte. En el sermón $16 \mathrm{~A}$, señalando en qué consiste la misericordia que se ha de tener con el hermano que se ensaña contra uno, dice: «sientes pena porque también él es tu hermano, es un miembro tuyo»93. Nada más lacónico, sobre todo teniendo en cuenta lo prolijo que suele ser en otras ocasiones cuando toca este tema. En el primer $\operatorname{Tr} C a J n$, la cita de Ga 6 aparece al hablar de la Iglesia en un con-

91. Sermón $164,10,15$.

92. RepPar 3,1,3.

93. Sermón $16 \mathrm{~A}, 7$ 
texto en que establece la distinción entre ella, cuerpo, y Cristo, cabeza, pero la realidad del Cuerpo Místico no tiene particular repercusión en la interpretación de Gal 6,2.

\section{h. Condición poder ver a Dios}

El santo cuenta todavía con otro recurso para estimular a sus oyentes o lectores. Consiste en infundir un sano temor y referirse a las consecuencias negativas que se seguirían para uno de no cumplir con el precepto apostólico: quedar excluido de la presencia del Señor. La expresa mediante un poderoso juego de palabras latinas: Melius enim ferres quam te ipsum efferres, es decir, es preferible llevar las cargas del hermano a quedar excluido de la compañía de los buenos, con referencia al juicio final ${ }^{94}$. A la exclusión de la visión de Dios hace referencia indirectamente también en CiudD. Condición para verle es lograr la paz (Hb 12,14) a la que se ordena el precepto del perdón de los pecados, una de las formas de llevar las cargas de los demás 95 .

No es raro que san Agustín establezca la relación de este precepto apostólico con la vida futura. Ya al comienzo anota que su aplicación se limita al tiempo que dura la peregrinación en esta tierra. El deber de la caridad que consiste en llevar las cargas de los demás, que no ha de durar siempre, conduce a la felicidad eterna, en que no habrá carga alguna que haya que llevar recíprocamente. Pero ahora, mientras nos hallamos en esta vida, debemos llevarlas para llegar a la otra ${ }^{96}$. Más tarde, en el sermón 88, ya en el ardor de la polémica antidonatista, insiste en que hay que tolerar la paja mientras dure la trilla en este mundo. En efecto, se trata de algo que sólo hay que tolerar ahora, puesto que no estará en el granero. El tolerar la paja lo interpreta como equivalente de llevar las cargas ajenas: a continuación cita Ga 6,297. En el sermón 91, cierra con Ga 6,2 una invitación a compartir toda clase de bienes. «Dando a quien está necesitado, lograremos merecer a Quien tiene en abundancia»98, en el tiempo final. De hecho, presenta tales obras de misericordia como las propias de quien camina en la fe hasta que llegue el momento de ver a Dios cara a cara.

94. Sermón $164,7,11$.

95. CiudD 15,6.

96. $83 D Q$.

97. Sermón 88,18,19-20.

98. Sermón 91,7,9. 
Cuando habla del pobre y del rico, cargados cada uno con el peso de su riqueza y de su pobreza, los muestra caminando a ambos por el camino del Señor, durante la peregrinación que es esta vida hacia la patria eterna ${ }^{99}$.

Por último, el ejemplo del comportamiento de los ciervos que aduce en tres textos para explicar Ga 6,2 tiene también una clara referencia escatológica, como se indicará más adelante.

\section{EL FRUTO}

En el sermón 164 el santo sólo se planteaba dos cuestiones a propósito de Ga 6,2: a qué cargas se refiere el apóstol y cómo han de ser llevadas. Esas eran efectivamente las dos cuestiones que creía necesitaban ser aclaradas a sus oyentes. Pero no agotan los aspectos que pueden considerarse. De hecho él mismo comenzó señalando el «fruto» (quo fructu) que reporta a los cristianos el llevar recíprocamente los unos las cargas de los otros. No lo señala como quaestio porque no lo percibía como tal, dado que lo señala el mismo texto: el cumplimiento de la ley de Cristo. Si los cristianos cumplen el precepto de llevar recíprocamente sus cargas, se produce en ellos como automáticamente (sua sponte) el fruto señalado, consistente en cumplir la ley de Cristo ${ }^{100}$. Esa especie de automatismo se comprende desde lo dicho en los apartados anteriores: la ley de Cristo es la ley del amor y el llevar las cargas sólo es posible mediante el amor. En realidad, más que consecuencia se da simultaneidad: en el mismo llevar las cargas, dado que es obra del amor, se está poniendo en acción la ley de Cristo.

Pero en otros textos el santo alude a nuevos frutos que es oportuno traer aquí. Para señalarlos podemos considerar a los dos sujetos, el que va cargado y el que le ayuda a llevar la carga; primero por separado y luego en cuanto miembros ambos de la comunidad eclesial. El fruto, pues, se recoge en tres niveles.

El primer beneficiado del cumplimiento del precepto del Apóstol es, sin duda, el hermano que arrastra con dificultad su carga. $\mathrm{Y}$ el beneficio que obtiene es precisamente poder verse liberado o sanado, según la imagen que se prefiera. La intervención en su ayuda apunta a ese objetivo. Así lo expresa, por ejemplo, en $83 D Q$. Utilizando la imagen médica, habla de la curación de la enfermedad. Llevar las cargas del hermano consiste en asumir la misma enfermedad de que se quiere librar al otro. Pero asumirla sólo en la justa

99. Sermón $164,7,9$.

100. Sermón $164,1,1$. 
medida, la necesaria para auxiliarle, no con el objetivo de participar sin más del mismo nivel de miseria. San Agustín pone el ejemplo de quien se inclina para tender la mano a quien yace en el suelo. No llega hasta el extremo de yacer como él en tierra; se limita a inclinarse tanto cuanto es necesario para levantar al caído101. Tal es el objetivo que se propone; el agacharse sólo es un medio para lograr ese fin. Más adelante, propone el ejemplo del apóstol Pablo, pero utilizando ahora la imagen de la liberación: si él se hizo todo por todos, a fin de ganarlos a todos, no tenía otra intención que liberar del vicio a los otros ${ }^{102}$. Respecto de estas cargas -los pecados-, no puede haber otro objetivo que el de hacerlas desaparecer o, al menos, quitarlas de los hombros de quienes sudan bajo su peso. Es obvio que la caridad no carga con ellas para salvaguardarlas, como quien carga con un pesado tesoro para ponerlo al abrigo de los ladrones. Los pecados son pesos que oprimen siempre, en el presente y en el futuro. De ahí que, después de hacer un largo elenco de las cargas maiores por las que pujaban los donatistas, comenta: «Todas estas cargas hemos intentado y estamos intentando deponerlas de los hombros de nuestros hermanos. Ellos las aman teniéndolas consigo; no quieren decrecer, puesto que con las mismas cargas se hincharon. En efecto, el que depone la carga que llevaba sobre sus hombros se hace como más pequeño; pero se había añadido un peso, no estatura»103.

Pero también sale beneficiado quien acepta llevar las cargas de los demás. En primer lugar porque tiene ahí el mejor de los criterios para medir su progreso en la vida del espíritu, dado que no hay nada que pruebe tanto si un hombre es espiritual o no como el modo de comportarse ante el pecado ajeno104, o la calidad de su amistad, dado que no hay nada que pruebe tanto si un hombre es verdadero amigo como el llevar las cargas del amigo105. En segundo lugar, por la misma reciprocidad: «ahora te llevo yo a ti, para que luego tú me lleves a mí». El principio que establece el obispo de Hipona es el siguiente: a aquel cuya debilidad queremos sobrellevar debemos prestar el servicio que quisiéramos recibir de él, en el caso de que la situación se hallase invertida ${ }^{106}$. En el ComSal 129 leemos: «... si perdonas, llevas la carga de tu hermano. Y si tú, como hombre que eres, caes tal vez en alguna debilidad, es preciso que él te lleve a ti como tú le has llevado a él»107. En dicho comenta-

101. $83 D Q 71,2$.

102. $83 D Q 71,4$.

103. Sermón 164,7,10.

104. Exp Ga 56.

105. 83DQ 71,1.

106. $83 D Q 71,4$.

107. ComSal 129,4. 
rio habla de quien, orando por el pecador, aprendió a llevar las cargas del hermano, para que también él lleve las suyas y se cumpla el precepto del Apóstol108. En ese dirección va también su interpretación de las palabras de Jesús al paralítico curado: Toma tu camilla y anda (Jn 5,8). Como ya se indicó páginas atrás, la camilla que lleva al enfermo es el prójimo; por tanto, «si cuando estabas enfermo te llevaba él a ti, ahora que el enfermo es él y el sano tú, llévale tú a él»109. Se trata, por tanto, de un comportamiento que, en virtud de la misma reciprocidad que ordena el Apóstol, reporta beneficios personales. Al prestar un servicio a otro que lo necesita, abre las puertas para que el otro se lo preste a él, cuando lo necesite. El cristiano que así actúa, además de cumplir el precepto apostólico, se beneficia personalmente.

Es cierto que no siempre se da la reciprocidad, y en un sermón el santo trata de orientar el comportamiento de la persona que siente el peso de la ingratitud110. Esta no debe ser motivo para que nadie se desanime, porque si no se obtiene la reciprocidad de parte del hombre, puede obtenerla de parte de Dios. El caso más evidente es el del perdón. Cuando un cristiano libera al prójimo de su carga otorgándole el perdón, Dios le libera de la propia, dado que sólo le perdona cuando él mismo perdona (Mt 6,12). Perdón que, en sí mismo, independientemente de la actitud que tome aquel a quien se le concede, produce su efecto curativo en el hombre que lo otorga. Llevar las cargas de los demás abre las puertas al mismo. Sólo así es posible recitar con la cabeza bien alta las súplicas que ha dictado el jurisperito celeste: Perdónanos nuestras ofensas como nosotros perdonamos a los que nos ofenden111.

En el sermón 163 B se lee: «Si no lleváis recíprocamente vuestras cargas, tendréis que dar cuenta negativa en el momento en que cada uno llevará su propia carga. Hacedlo (no descuidar la herida del prójimo), de modo que llevéis recíprocamente vuestras cargas y os perdone Dios la que cada uno ha de llevar personalmente. Pues, si llevas la carga del otro cuando él se ha deslizado en algún pecado, llegarás al lugar donde oíste: Cada uno llevará su propia carga, y con buena conciencia podrás decir a Dios: Perdónanos nuestras deudas»112. Aunque el hombre no responda, el que perdona siempre obtendrá la reciprocidad, si no del hombre, sí de Dios. Si no alivia del peso el hombre, alivia Dios. ¿Cómo alivia a los que están cargados de pecados? Obviamente con el perdón de los mismos ${ }^{113}$.

108. Cf. ComSal 129,4 .

109. TrEvJn 17,9 .

110. Sermón $164,7,8$.

111. ComSal 129,4.

112. Sermón 163 B,3.

113. Sermón $164,2,4$. 
El fruto se da también a nivel eclesial. En el contexto de la predicación de san Agustín, tanto el que va cargado como quien le ayuda a llevar la carga aparecen como cristianos, es decir, miembros de la Iglesia. El fruto inestimable que para ella se deriva es el de mantener el valor supremo de la unidad. Tal es el sentido de la asociación que hemos visto entre $\mathrm{Ga} 6,2$ y Ef 4,2-3. Al llevar recíprocamente las cargas, esto es, al tolerarse mutuamente, se mantiene la unidad del Espíritu en el vínculo de la paz. La relación entre ambos textos va en ambas direcciones: unas veces precede Ga 6,2 y sigue Ef 4,2-3, mostrando que al cumplirse lo primero (llevar las cargas) se hace realidad lo segundo (mantener la unidad y la paz), y otras precede Ef 4,2-3 y sigue $\mathrm{Ga}$ 6,2 , indicando que para mantener la unidad y la paz es preciso llevar recíprocamente las cargas. Ponderar el valor que tienen en la eclesiología agustiniana el valor de la unidad y de la paz, no entra ahora en nuestros intereses. Baste señalar que, en virtud de la estrecha correlación entre ambos, del valor que asigna el santo a la unidad eclesial se puede deducir el que asigna al llevar recíprocamente las cargas. En todo caso, es preciso señalar que en los textos considerados, él se limita a citar el texto de Ef 4,2-3 sin entrar en desarrollos ulteriores. Sin duda, sus oyentes ya conocían la importancia que le asignaba por otras predicaciones y sus lectores por otros textos ${ }^{114}$.

\section{MODOS CONCRETOS DE LLEVAR LOS UNOS LAS CARGAS DE LOS OTROS}

La segunda de las dos cuestiones que el santo se planteaba a propósito de Ga 6,2 en el sermón 164 era: «¿Cómo han de llevarse las cargas?». Esto es, ¿cuáles son los modos concretos como se puede hacer realidad el precepto apostólico? Dado el carácter de los textos, unos de predicación que nunca pretenden un tratamiento completo y orgánico del texto comentado, y otros puramente ocasionales, es normal que no se encuentre en ninguno de ellos una exposición sistemática. Sin embargo, conjuntando los textos se obtienen varios y significativos elementos dignos de consideración ${ }^{115}$.

114. El texto es uno de los privilegiados en la polémica entre católicos y donatistas. Cf., limitándonos a escritos de este período: Carta 43,8,23; 44,5,11; 210,1; RepPar 3,2,16; RepPet 2,15,35; 2,69,155; 2,78,174 (citado por Petiliano); El bautismo 1,9,12; 1,18,28; 2,6,8; 6,7,10; 6,22,39; 7,51,99; Réplica al gramático Cresconio 4,8,10 ComSal 143,2; Sermón 88,21; 260 A (=Denis 8),2.3.

115. A.M. La Bonnardière se limita a «quelques cas éminents de son application: dans l'amitié des chrétiens, dans la vie communautaire des moines, dans le devoir austère de la correction fraternelle», en tres apartados con los siguientes epígrafes: Le cerf de l'amitié, La frange du vêtement sacerdotal, La miséricorde des spirituels. Cf. art. cit. pp. 207-215. 


\section{a. Llevar las cargas como tolerancia}

Una primera forma, genérica, de llevar las cargas de los demás consiste en «soportar» con paciencia las debilidades físicas y morales de los demás. De hecho, el santo sustituye con frecuencia el portare (llevar) del texto con otros verbos que significan tolerar, soportar, aguantar, etc.116. Funcionan en la práctica como sinónimos. Valga como ejemplo: «... llevemos (portemus) recíprocamente nuestra cargas. Amando a Cristo, fácilmente soportamos (sustinemus) la debilidad del otro»117. No se trata en ningún modo de una actitud estoica, consecuencia de considerar la situación como irremediable, ni nace del desinterés hacia el hermano. Al contrario, en el origen de esa actitud de tolerancia y aguante está precisamente el interés por él y el convencimiento de que puede superar dicha situación si se le ayuda y se le da tiempo. El mal del hermano, más que suscitar desinterés en los demás, provoca dolor ${ }^{118}$ y desagrado119. Cuando la tolerancia es auténticamente cristiana, tampoco nace de una conciencia exacerbada de la propia superioridad que conduce al desprecio de los demás. El santo deja bien claro que el llevar las cargas de los otros no se compagina con el gozarse o gloriarse de la propia justicia o méritos frente a los pecados del prójimo ${ }^{120}$.

Es evidente que este lenguaje está determinado en parte por Ef 4,2-3, tan frecuentemente asociado a $\mathrm{Ga}$ 6,2, y por las circunstancias concretas de división eclesial de entonces. Sobre todo en ciertos momentos en que la actividad en favor de la unidad y la paz eran intensas, el pastor insiste a sus fieles en la necesidad de ser tolerantes, de no exasperar los ánimos de los cismáticos. Es verdad que numerosos textos parecen reclamar una actitud más bien pasiva; pero conviene añadir que son más los que presentan otras formas muy concretas y activas que vamos a ver a continuación.

\section{b. Llevar las cargas como acomodarse a las deficiencias físicas de los demás}

En un sermón, texto único al respecto, san Agustín pide a sus oyentes que se mantengan quietos y así podrán oirle mejor. Después de indicar que si no

116. Por ej., tolerare (83DQ 71,2.6; InIoEp 1,12; Sermón $163 \mathrm{~B}, 2)$, sustinere (83DQ 71,7; Sermón 164,1,2); ferre (InIoEp 1,12; Sermón 164,6,8; 7,11; 9,15); sufferre (CParm 3,2,5); perferre (RepPar 3,2,5).

117. $83 D Q 71,7$.

118. RepPar 3,2,4.5; Sermón 16 A,7.

119. ComSal 129,4.

120. RepPar 3,2,4.5. 
se están quietos no les llegará su voz'121, y cuán pronto oyen, aunque no se hable demasiado alto, los que no alborotan, continúa: «Por tanto, ayudadme vosotros, conforme a lo que está mandado en la Escritura: llevad mutuamente vuestras cargas, para que recibáis todos a la vez lo que a todos se os da»122. San Agustín alude con frecuencia en los sermones a su poca voz ${ }^{123}$. En esa situación, los fieles ayudan a su obispo a llevar esa carga facilitando con su comportamiento que pueda hacerse oir ${ }^{124}$.

\section{c. Llevar las cargas como comunión de bienes}

Al hablar de las cargas, se indicó que entre ellas había que incluir tanto la pobreza como la riqueza. A partir de ahí, es fácil comprender que una de las modalidades del llevar recíprocamente las cargas que recomienda el Apóstol consista en compartir los bienes materiales. Después de referirse a la carga del amor, dice en un sermón: «Vuelve ahora también la atención al precepto: Llevad recíprocamente vuestras cargas (Ga 6,2). Tal es, en efecto, la carga que te ha impuesto Cristo; gracias a ella podrás compartir con el otro la propia. Tú eres pobre, él es rico; a él le pesa su pobreza, un peso del que careces tú. Estáte atento a no decir, cuando él requiera tu ayuda, Cada uno llevará su propia carga (Ga 6,5). Es el momento de escuchar este otro precepto: Llevad reciprocamente vuestras cargas (Ga 6,2). - "La pobreza no es peso que me oprima a mí, sino a mi hermano"-. Piensa si no te oprimen aun más a ti las riquezas. No te pesa la pobreza, pero sí la riqueza. Si bien lo piensas, es una carga. Aquel tiene una, tú otra. Ayúdale a llevar la suya y de esa forma lleváis recíprocamente vuestras cargas. ¿En qué consiste la carga de la pobreza? En no tener. ¿Y la de las riquezas? En tener más de lo necesario. Uno y otro vais cargados. Carga con él el no tener; cargue él contigo el tener más de lo necesario, para que se igualen vuestras cargas. Si das a quien está necesitado, le disminuyes su peso llamado "no tener"; al darle, empieza a tener; se ha reducido el peso de no tener; a su vez, él ha aligerado el tuyo, de nombre

121. Esta idea la expresa bellamente de esta manera: «iter uocis nostrae quies vestra est» (La ruta de mi voz es vuestro estaros quietos).

122. nuevo Sermón; cf. nota 4.

123. Cf. Sermones 37,$1 ; 139$ A,2; 153,1; 154,1; 294,19; etc.

124. Cf. también Sermón 101,7, en que el santo responde a quien, amparándose en Lc 10,4 , pretende cumplir el evangelio, por caminar descalzo. La respuesta del obispo deja entrever en el trasfondo Ga 6,2: "Yo -dirá alguno- cumplo el evangelio, pues camino descalzo". Bien, tú puedes, yo no. Guardemos lo que uno y otro hemos recibido. Inflamémonos en la caridad, amémonos mutuamente, y de esta forma yo amo tu fortaleza y tu soportas mi debilidad». 
"tener más de lo necesario". Los dos avanzáis por el camino del Señor mientras dura la peregrinación en que consiste esta vida temporal; tú cargado con enormes y superfluos atuendos; él, sin ninguno. Se juntó a ti deseando ser tu compañero; no lo desprecies, no lo abandones. ¿No adviertes cuán grande es el peso que arrastras? Cede una porción a quien nada lleva y nada tiene. Así ayudarás a tu acompañante y tú te sentirás aliviado. En mi opinión ha quedado suficientemente explicada la frase del Apóstol»125. El predicador ha señalado una forma de entender la carga de la pobreza; pero es la única, como se verá a continuación.

En el largo texto citado el santo se ha referido sólo a las riquezas materiales, como resulta del contexto. Los bienes terrenos son un peso para los dos: para uno, por escasez; para otro, por abundancia. En este caso se puede establecer la reciprocidad: los dos pueden aligerarse recíprocamente respecto del peso originado por los bienes de la tierra.

En otro sermón amplía el concepto del compartir a todos los bienes, tanto físicos como espirituales. El texto es muy explícito y concreto al respecto. Dice así: «Caminando en la fe, obremos el bien. Sea desinteresado el amor a Dios manifestado en las buenas obras; el amor al prójimo sea constructor del bien. Nada tenemos que podamos dar al Señor; pero como tenemos qué dar al prójimo, dando al necesitado, mereceremos a Quien tiene en abundancia. Por tanto, cada cual ponga a disposición del otro lo que tiene; otorgue al necesitado lo que tiene de más. Uno tiene dinero: alimente al pobre, vista al desnudo, levante la iglesia, obre con su dinero todo el bien que pueda. Otro posee el don de consejo: gobierne al prójimo, disipe las tinieblas de la duda con la luz de la piedad. Un tercero tiene ciencia: dé de la despensa del Señor, sirva el alimento a sus consiervos, conforte a los fieles, invite a volver a los que yerran, busque a los perdidos, haga cuanto esté en su mano. Hay algo que también los pobres pueden ofrecer: uno puede poner sus pies al servicio de un cojo, otro prestar sus ojos como guía a un ciego; uno visite al enfermo, otro dé sepultura a un muerto. Estas cosas están en las posibilidades de todos, de forma que es muy difícil hallar a uno que no tenga nada que pueda poner a disposición del otro. En esto consiste la recomendación concluyente y suprema del Apóstol: Llevad recíprocamente vuestras cargas y así cumpliréis la ley de Cristo»126. A tenor de este texto, llevar recíprocamente los unos las cargas de los otros consiste en poner a disposición de los demás toda clase de bienes: los exteriores al hombre (las riquezas) y los que le son personales, tanto de naturaleza física (los sentidos sanos) como espiritual (ciencia y sabiduría). 


\section{d. Llevar las cargas como oración}

La primera referencia de san Agustín a este texto apostólico es posterior de poco a su ordenación sacerdotal. Aparece en la carta 22, del 392, dirigida al obispo de Cartago, Aurelio. El santo le ha hablado de los vicios de los clérigos, entre los que enumera la rivalidad y la envidia, cuya madre es la soberbia y avidez de alabanzas humanas que, con frecuencia, engendra también la hipocresía. Luego hace una confesión personal que concluye con estas palabras: «Lucho a diario con mi adversario y con frecuencia caigo herido, cuando no puedo reprimir la complacencia ante la lisonja que me tributan». A continuación añade: «He consignado todo esto... para que conozcas mis debilidades, y así te dignes rogar a Dios por ellas. Te suplico que lo hagas con ahínco, por la humanidad de quien nos dio el precepto de llevar recíprocamente nuestras cargas»127. La oración ante las debilidades del hermano aparece, pues, como una forma de cumplir con el precepto del Apóstol. Desde el punto de vista cronológico, la primera que presenta el santo.

La primera, pero no la última. En un texto de predicación, del 407, podemos leer a propósito de quien se encuentra ante una acción pecaminosa de otro: «Si te desagradó, si oraste por él... aprendiste a llevar las cargas de tu hermano, para que también él lleve las tuyas, si existen, y se cumpla en vosotros lo que dice el Apóstol: Llevad recíprocamente vuestras cargas y así cumpliréis la ley de Cristo»128. El santo no indica el sentido de esa oración por ser evidente: súplica a Dios para que haga desaparecer lo que la provoca. Ya se habló de ello con anterioridad.

\section{e. Llevar las cargas como perdón}

El quinto modo de llevar las cargas se identifica con la exigencia de otorgar el perdón al hermano que ha pecado. Es lo que expresa otra serie de textos que vimos asociados a Ga 6,2: Mt 6,12; 9,12; 18,23-35; Ef 4,26.

El primer texto que asocia expresamente Ga 6,2 y el perdón es del 407 . Comentando el salmo 129,4: Gracias a tu ley he resistido ante ti, señala que se trata de la ley de la misericordia, es decir, Mt 6,12: Perdona nuestras ofensas como nosotros perdonamos a los que nos han ofendido. Y continúa: «He esperado que vengas y me libres de toda necesidad, pues ni en la misma necesidad dejaste de ofrecer la ley de la misericordia. Escucha a qué ley se refiere, si aún

127. Carta 22,2,7-9.

128. ComSal 129,4. 
no has entendido que se refiere a la ley de la caridad. Escucha al apóstol: Llevad recíprocamente vuestras cargas y asi cumpliréis la ley de Cristo. ¿Quiénes llevan recíprocamente sus cargas sino los que tienen la caridad? Los que no tienen la caridad se resultan recíprocamente gravosos; en cambio, quienes la tienen, llevan recíprocamente sus cargas. Alguien te ha dañado y te pide perdón; si no le perdonas, no llevas la carga de tu hermano; si le perdonas, llevas al enfermo. Y si tú caes enfermo de algo, como hombre que eres, es preciso que te lleve también el otro, como tú le llevaste a él». A continuación, hablando del comportamiento que el cristiano ha de mantener con quien le ha dañado, dice: «Si te desagradó, ... si le otorgaste el perdón cuando te lo suplicó, de modo que puedes recitar con la frente alta las súplicas que te redactó el jurisperito celeste: Perdona nuestras ofensas como también nosotros perdonamos a los que nos ofenden (Mt 6,12), aprendiste a llevar las cargas de tu hermano, para que también él lleve las tuyas, si existen, y se cumpla en vosotros lo que dice el Apóstol: Llevad recíprocamente vuestras cargas y así cumpliréis la ley de Cristo»129.

De forma aún más clara y explícita lo afirma en el mismo pasaje, un poco más adelante. Comentando el mismo salmo asocia tres textos: Sal 129,3; Mt 6,12 y Ga 6,2. Más en concreto, considera la multitud de pecados que todo hombre conoce y que da razón del grito del salmista: Desde lo hondo a ti grito, Señor (Sal 129,1). Luego continúa el predicador: «Puedo evitar los homicidios, los adulterios, las rapiñas, los juramentos en falso, los sortilegios; pero ¿puedo evitar los pecados de la lengua? ¿y los del corazón? Efectivamente está escrito: El pecado es la iniquidad (1 Jn 3,4). Siendo esa la realidad, si el Señor toma en cuenta las culpas, ¿quién resistirá? (Sal 129,3). Si quieres actuar con nosotros como juez severo, no como padre misericordioso, ¿quién resistirá en pie tu mirada? Pero en ti se halla la propiciación; gracias a tu ley, te he aguantado, Señor. ¿De qué ley se trata? Llevad recíprocamente vuestras cargas, y así cumpliréis la ley de Cristo (Gal 6,2). ¿Quiénes llevan mutuamente sus cargas? Quienes dicen sinceramente: Perdona nuestras ofensas como nosotros perdonamos a los que nos han ofendido ( $\mathrm{Mt} 6,12) » 130$.

Como va a ser citado en el apartado siguiente, baste aludir aquí a un texto del sermón 16 A. En él aparece el perdón, junto con la oración y la corrección, como forma de llevar los unos las cargas de los otros. El texto es sobrio y se limita a ofrecer el perdón dentro de la corrección fraterna. Un perdón que parece otorgado «gratuitamente», es decir, sin que aparezca expresado que es la condición para que Dios perdone las propias faltas, de acuerdo con

129. ComSal 129,3-4.

130. ComSal 129,5. 
Mt 6,12. Pero, obviamente, subyace. Digno de resaltar también: es el único texto en que aparece la exigencia del perdón en la forma negativa de renunciar a la venganza, aunque sea en la modalidad de pedir a Dios que pague al calumniador según lo que merece ${ }^{131}$.

El último texto que explícitamente vincula $\mathrm{Ga}$ 6,2 y el perdón de los pecados es el de la CiudD. En atención a la enfermedad -dice el santo- que, a consecuencia del pecado, sufren todos los hombres, se nos ha ordenado que llevemos recíprocamente los unos las cargas de los otros. Primero presenta los textos que considera semánticamente paralelos a $\mathrm{Ga} 6,2$, todos ellos relativos a la corrección fraterna y que veremos en el apartado siguiente, con la única excepción de Ef 4,26, que se coloca en el ámbito del perdón, sin mencionarlo: Que la puesta del sol no os sorprenda en vuestro enojo. Luego añade: «Por eso, también con respecto al perdón recíproco, existen muchas prescripciones, poniendo en ellas énfasis especial, para mantener la paz, sin la cual nadie podrá ver a Dios (Heb 12,14)», y concluye señalando el terror que infunde la parábola del siervo al que se le perdonó una cantidad ingente y que no fue capaz de perdonar otra insignificante a su consiervo (cf. Mt 18,35). El texto respira los aires de la polémica antipelagiana al hablar de la enfermedad que padecen los ciudadanos, aún peregrinos, de la ciudad de Dios y que suspiran por la patria eterna. Tanto la corrección como el perdón son presentados como medicación de uso exterior, pero que produce su efecto interior por obra del Espíritu Santo132.

Los textos han dejado claro que el perdón constituye otra forma concreta de cumplir el precepto apostólico.

\section{f. Llevar las cargas como corrección}

De las múltiples formas concretas de cumplir el precepto apostólico que presenta el santo hay una que destaca sobre las demás: la corrección fraterna133. El hecho no debe extrañar si se tiene en cuenta el contexto. Ga 6,2 for-

131. Sermón $16 \mathrm{~A}, 7$.

132. CiudD 15,6 .

133. Los textos agustinianos que versan sobre la corrección fraterna son muy numerosos. La consideración de todos ellos contribuiría sin duda a la comprensión más exacta de este modo de llevar las cargas de los demás. Aquí nos limitamos a aquellos que aparecen directamente vinculados a Ga 6,2. Sobre la corrección fraterna, cf. A. CLERICI, Ama e fà quello che vuoi, Palermo 1991, p. 89-154; M.-Fr. Berrovard, Bibliothèque Augustinienne 71, nota complementaria 74: «El deber de la corrección», p. 912-914.

Ya antes de san Agustín, habían señalado la relación que existe entre Ga 6,1-2 y la pastoral de la corrección fraterna Mario Victorino (In Epistolam Pauli ad Galatas VI,2), san 
mula un principio general, como consecuencia de la exhortación concreta de Ga 6,1134. Aquí el apóstol exhorta a los espirituales a instruir con suavidad al hermano que hubiera sido sorprendido en alguna falta. San Agustín interpreta en el sentido de corrección el «instruir con suavidad». Ello explica que muchos de los textos que hemos visto aparecer en conexión con $\mathrm{Ga}$ 6,2 tengan como denominador común la invitación a ejercitar la corrección: además del texto de Ga 6,1 ya mencionado, Mt 18,15; Ef 5,11; 1 Ts 5,14-15; 1 Tm 5,20 y $2 \operatorname{Tm} 2,24-26$.

Como es comprensible, san Agustín interpreta $\mathrm{Ga}$ 6,2 en clave de corrección fraterna en los textos correspondientes al período en que era más intensa su polémica con los donatistas. En él intensifica sus recomendaciones de la misma. Sirva como ejemplo un texto del sermón 88 que concluirá citando $\mathrm{Ga}$ 6,2. Después de señalar, como apostilla contra los donatistas, que en la Iglesia hay buenos y malos, pero que la separación entre unos y otros la efectuará el Señor en su debido momento, añade, dirigiéndose a los católicos: «Y no seáis negligentes en corregir a los vuestros, es decir, a los que de cualquier modo están bajo vuestra custodia, amonestándoles, enseñándoles, exhortándoles, infundiéndoles temor. Obrad de todas las maneras que os sea posible. Y no os hagáis perezosos para corregir a los malos...»135.

Repetidamente se muestra preocupado el pastor por la desidia de sus fieles al respecto. Desidia que quiere sacudir, pues la considera un gran pecado: «Si te resulta insoportable el pecado de tu hermano y a él el tuyo, recíprocamente os desentendéis el uno del otro (neglegitis) y cometéis un gran pecado» ${ }^{136}$. Gran pecado que se convierte en una carga. Si uno se desentiende (si neglexeris) de la herida del hermano, ha de dar cuenta, negativa, de su pecado de desidia (de peccato neglegentiae suae) y éste se convertirá en una carga cuyo peso tendrá que llevar personalmente ${ }^{137}$. La desidia de que habla se refiere específicamente a desentenderse del deber de la corrección.

En el sermón 164 da razón de por qué san Pablo escribió Ga 6,2 con estas palabras: «Contra aquellos a quienes, aferrándose a esto -la afirmación del Apóstol de que cada cual llevará su propia carga ( $\mathrm{Ga}$ 6,5)-, se les pudiese infiltrar la desidia (neglegentia), de modo que, adquirida la seguridad de que

Cipriano (Epistula 55,18,1), Optato de Milevi (De schismate donatistarum 7,3) y san Jerónimo (Comment. in epist. ad Gal. III, 6,2). Cf. A. M. LA BonNARDiere, art. cit. p. 210-211.

134. «Et cum admonuisset illos, id est spirituales (=Ga 6,1), intulit continuo generalem illam sententiam (=Ga 6,2)» (Sermón 163 B,4)

135. Sermón 88,18,19.

136. Sermón 163 B,2. Sobre la misma negligencia, cf. también Sermón 164,2,3 y Sermón $88,17,20$.

137. Sermón $163 \mathrm{~B}, 3$ 
no se contaminan con los pecados ajenos, no se preocupasen de corregir a nadie, dijo: Llevad recíprocamente vuestras cargas»138.

Respecto de la corrección hay que distinguir dos casos: el primero, la corrección entre iguales, en el ámbito de la común fraternidad cristiana, y la segunda la hecha a personas en régimen de dependencia de otra. En este apartado nos ocupamos sólo del primero.

Un texto nos lo ofrece el sermón $16 \mathrm{~A}$. El pasaje es significativo por el triple modo como señala que se pueden llevar recíprocamente las cargas: además de la corrección -aunque aquí no usa ninguno de los términos habituales-, la oración y el perdón, modos ya señalados. Está hablando de uno que ha sufrido una calumnia de boca de otro. Tras unas normas concretas sobre cómo ha de comportarse, añade: «Se ha dicho: Llevad vuestras cargas y así cumpliréis la ley de Cristo. Cuando él hable, tú calla. Después, cuando se haya tranquilizado, dile: "Hermano, por tu bien, ¿por qué me echaste en cara lo que no hice? Pecaste contra mí, pero yo ruego a Dios por ti. Yo te ofrezco el perdón y ruego por ti a Dios, a quien injuriaste al pecar contra mi. No lo vuelvas a hacer. No te ensoberbezcas. No ruego a Dios que te pague conforme a tu calumnia"»139. Es un ejemplo de la corrección llevada a cabo entre hermanos y con la máxima delicadeza: el reproche es sustituido por la pregunta y la exhortación a no volver a hacer lo reprobable. La corrección comienza y acaba en la palabra.

En otro texto, también del período álgido de la lucha antidonatista, el pastor se expresa así: «Llevad recíprocamente vuestras cargas y así cumpliréis la ley de Cristo. ¿Qué significa el llevar recíprocamente las cargas?... No os desentendáis (nolite neglegere) recíprocamente de vuestros pecados. Censurad (arguite) a aquellos con quienes tenéis confianza; amonestad (admonete) a los otros, si no tenéis confianza para censurarlos, y, si es necesario, para que nadie peque, suplicad, rogad. ¿Acaso os he humillado al decir "rogad"? Escuchad al Apóstol: Al mandároslo, dijo, os rogamos que no recibáis en vano la gracia de Dios (2 Co 6,1)»140. El ámbito de la corrección aquí aludido es el primero de los señalados antes. El santo no alude a dependencia de ningún tipo entre quien ha de corregir y quien ha de ser corregido, sino a la simple confianza que puede existir o no existir. Y es además ese nivel de confianza el que determinará el modo de intervención y el nivel de dureza que se puede emplear. Son significativos los verbos utilizados. En tono des-

138. Sermón $164,2,3$.

139. Sermón 16 A,7.

140. Sermón 163 B,4. De modo parecido se expresa en su escrito a Parmeniano: «et agendum voto et precibus, si corrigi obiurgationibus non potest» (RepPar 3,1,3). 
cendente: censurar ${ }^{141}$, amonestar, rogar. A continuación pone un ejemplo que insiste en la consideración de tener en cuenta la situación anímica de quien ha de ser corregido: «Si el enfermo se halla aún con fuerzas, el médico le regaña (corripit); si, en cambio, no las halla y teme que fallezca por la amargura de la regañina (correptionis), le suplica y le ruega que le escuche, que haga lo que le dice y siga con vida» ${ }^{142}$.

Todavía queda un texto, el más tardío de todos, que ya vimos al tratar del perdón. En CiudD presenta dos formas de llevar los unos las cargas de los otros. A la primera, el perdón, ya hicimos referencia; la segunda es la corrección. Respecto de esta no hace comentario alguno, pero aduce una colección de textos del Nuevo Testamento referentes a la corrección que aporta para explicitar Ga 6,2. Baste recordarlos: 1 Ts 5,14-15; Ga 6,1; Mt 18,15 y 1 Tm 5,20143. Si bien Mt 18,15 permite pensar que el santo tiene en mente lo dicho en el presente apartado, 1 Tim 5,20 sugiere lo que se tratará en el siguiente.

\section{g. Llevar las cargas como imposición de la disciplina eclesial}

Queda todavía otro modo de llevar a la práctica el precepto apostólico que hemos denominado «imposición de la disciplina eclesial». Sin duda cae dentro de la corrección fraterna porque busca el enderezamiento de quien se ha torcido, pero en cierto modo la sobrepasa. En este caso, la «corrección» la ejercen personas constituidas en algún tipo de autoridad, que no sea sólo moral, sobre otras que les están subordinadas. El deber de intervenir cuando el hermano se ha apartado del camino recto no se lo impone sólo la simple condición de cristianos, sino también el cargo específico que desempeñan dentro de la comunidad.

En el texto del sermón 88 citado en el apartado anterior, el obispo de Hipona exhortaba a sus fieles a no ser negligentes en corregir a aquellas personas «que tienen bajo su custodia» al amparo de cualquier título. Indicaba también algunos modos concretos, de los cuales merece atención el último: infundir temor (terrere). Este aspecto, asociado al castigo, no aparece en la corrección entre hermanos examinada en el apartado anterior; en la mente del santo sólo cabe en este segundo caso ${ }^{144}$. La desidia en la corrección, sigue

141. Arguere implica más dureza que corripere (cf. Comsal 6,3). Sobre el significado de los términos aquí utilizados por san Agustín, cf. S. POQUE, La langage symbolique dans la prédication d'Augustin d'Hippone. Images herö̈ques, Tome I (texte), Paris 1984, pp. 199-203.

142. $i b$.

143. CiudD 15,6.

144. Un texto distingue tres casos que requieren un comportamiento distinto: «No pienses que amas a tu siervo cuando no le pegas (caedis), o a tu hijo cuando no lo disciplinas (das 
diciendo el predicador, la provoca en algunos la enseñanza de la Escritura según la cual los malos no contaminan a los buenos que viven con ellos. Llegado a este punto, cita Ef 5,11, haciendo hincapié en las dos partes del precepto del Apóstol: no comulgar con las obras infructuosas de las tinieblas y redargüirlas. El «no comulgar» lo equipara con «no dar consentimiento, no alabar, no aprobar», y el «redargüir» con «reprender (reprehendere), corregir (corripere) y coercer (coercere)». Luego continúa: «En la corrección (correctione) o coerción (coercitione) de los pecados ha de evitarse que quien la ejerza caiga en el orgullo. Hay que pensar siempre en aquella otra sentencia del Apóstol: Quien piensa estar en pie, cuide no caer (1 Co 10,12). Aunque al exterior suene dura la reprensión severa (increpatio), interiormente ha de mantenerse la suavidad del amor». El proceder que acaba de describir al hilo de Ef 5,11, lo ve confirmado por Ga 6,2, que cita a continuación junto a $2 \mathrm{Tm}$ 2,24-26. Luego concluye: «No seáis, pues, tan benévolos con los malos que les deis aprobación, ni tan negligentes que no les censuréis (arguatis), ni tan soberbios que, al censurarlos (arguatis), se sientan insultados»145. Con estas últimas palabras se refiere al modo de ejercer la corrección. Interiormente, no ha de estar impulsada por el orgullo; exteriormente, el que la recibe no ha de sentirla como un insulto. La novedad en este texto está en la introducción de la coerción. Si los otros señalan acciones que caben en quien corrige desde la simple autoridad moral, el coercere sólo cabe en quien tiene potestad sobre otro.

En un desarrollo de la RepPar que acabará con la cita de Ga 6,2, leemos: «Si uno llega a despreciar la disciplina de la Iglesia hasta el punto que descuide el advertir (monere), el corregir (corripere) y el censurar (arguere) a los malos con quienes él no peca ni colabora o, si él ostenta el cargo y ello es posible sin menoscabo de la paz eclesial, descuida incluso apartarle de la participación en los sacramentos, no peca por pecado ajeno ninguno, sino con pecado personal»146. En este texto, el obispo distingue netamente entre el simple fiel y el que ostenta un cargo de responsabilidad en la comunidad eclesial. La corrección que, conforme a la disciplina de la Iglesia, exige del primero se efectúa mediante tres acciones que ya conocemos: advertir (monere), corregir (corripere) y censurar (arguere); en cambio, al segundo le exige algo más: apartar de la participación de los sacramentos en virtud del cargo que ostenta.

disciplinam), o que amas a tu vecino cuando no lo corriges (corripis): esto no es caridad, sino dejadez». En los dos primeros casos, el padre o el amo tienen autoridad sobre el hijo o siervo, y de ahí el nivel de dureza; no en el tercero, por lo cual el santo habla sólo de corregir (verbalmente) (TrCaJn 7,11).

145. Sermón 88,18,19-20.

146. RepPar 3,1,2. 
Todavía otro texto. Se trata del sermón 164 que -recordemos- está todo él dedicado a comentar Ga 6,1-5. El predicador se dirige a un fiel que se portó bien con otro, que luego se mostró ingrato con él. Le exhorta a no arrepentirse del bien realizado, para no vaciar con su pesar lo que había llenado con su misericordia; a no mirar a quien hizo el bien, sino a aquel por quien lo hizo; a no temer hallarse en la iglesia al lado de avaros o ladrones. Y prosigue de esta manera: «Sabes que es así, que es un fiel o, mejor, que se llama fiel. Por eso no puedes expulsarlo de la iglesia, no tienes posibilidad alguna de hacerle cambiar (corrigere) mediante el castigo (castigando) o la simple corrección (corripiendo)»147. Aquí introduce el castigare, al lado del corripere como medio para conseguir la corrección, pero no ha señalado aún el sujeto que puede aplicarlo. Se trata de la persona que tiene potestad para juzgar, como lo indica un poco más adelante: «Si has sido constituido juez, si has recibido poder de juzgar, si le acusan ante ti y resulta convicto del pecado mediante pruebas y testigos veraces, coércele (coerce), corrígele (corripe), excomúlgale (excomunica), degrádale (degrada) en conformidad con la norma eclesiástica. Haya tolerancia, pero sólo hasta donde lo permita el mantenimiento de la disciplina (sic vigilet tolerantia, ut non dormiat disciplina)»148. A excepción del corripere, los demás verbos señalan acciones que no pueden emprender los simples fieles, sino que competen a fieles constituidos en autoridad.

Los textos citados o bien surgen como comentario a $\mathrm{Ga} 6,2$ o bien encuentran en Ga 6,2 la confirmación de la enseñanza que proponen. Con otras palabras: el llevar los unos las cargas de los otros se efectúa también, en determinados casos, mediante la aplicación de normas disciplinarias; dicha aplicación, obviamente, sólo está en manos de quien tiene potestad para ello, y requiere, además, las suficientes garantías legales, como indica el texto citado. Tales medidas no tienen carácter vengativo, sino simplemente correctivo o curativo.

\section{UN EJEMPLO}

El salmo 41 reproduce el lamento de un desterrado. En él el salmista se compara con el ciervo, del que pondera su correr veloz hacia las fuentes cuando está sediento. El comentarista añade otros datos referentes a él que pudo leer en Plinio el Antiguo' ${ }^{149}$. El primero, que mata a las serpientes que encuen-

147. Sermón $164,6,8$.

148. Sermón 164,7,11.

149. Cf. Historia Natural 8,32. 
tra. Esto le provoca mayor sed, por lo que, después de darles muerte, corre aún más veloz a las fuentes. Interpretando las serpientes como símbolo de los vicios, añade esta exhortación: «destruye las serpientes de la maldad y, entonces, desearás más la fuente de la verdad»150. El segundo, determinado modo de proceder: cuando atraviesan un estrecho, forman filas y cada uno apoya la cabeza en la grupa del que tiene delante, mientras el cabecero se va turnando. El dato nos interesa aquí porque las tres veces que lo menciona aparece asociado a $\mathrm{Ga}$ 6,2151. La asociación le resultaba fácil. La cornamenta es ciertamente una carga para el ciervo; carga que, según el ejemplo, se ayudan a llevar mutuamente, al apoyarla cada uno en la grupa del delantero y permitir, a su vez, que el posterior la apoye sobre la suya.

Lo esencial del relato es idéntico en los tres textos, pero con particulares que merecen ser resaltados. El primero, de la época del presbiterado, pone el acento en el aspecto escatológico y, a través de Pr 5,19 que habla del ciervo de la amistad, lo coloca en el ámbito de la amistad cristiana, pues concluye «nada prueba tanto que un hombre es verdadero amigo como el llevar las cargas del amigo»152. El comportamiento descrito se produce cuando hacen la travesía de un estrecho hasta que llegan a la estabilidad de la tierra o tierra estable (donec veniant ad terrae stabilitatem). Esta tierra estable no simboliza otra cosa que la vida bienaventurada. Resulta claro de las páginas anteriores, en que ha contrapuesto la vida eterna, en que no habrá cargas que haya que llevar recíprocamente, a esta vida en que sí hay que llevarlas, «para poder llegar a la vida que carece de toda carga».

Este motivo escatológico aparece también en el ComSal 129: «De esa manera todos llevan las cargas de todos y llegan a la meta deseada y no padecen naufragio, porque la caridad les hace de nave»153. La referencia a la meta deseada (ad quod desiderant) es en el ejemplo un claro símbolo escatológico, pues no cabe duda que para el santo no tiene otra interpretación simbólica que la contemplación o disfrute de Dios. Este texto destaca el hecho de que la caridad es la nave segura que evita el peligro del naufragio.

El relato del ComSal 41, por el contrario, se caracteriza por poner el acento en el aspecto comunitario, al indicar tanto el momento: «cuando en su manada caminan por tierra o pasan a nado a otras tierras», como los efectos que se siguen de su proceder: «Y así, ayudándose mutuamente a llevar lo que resulta pesado, cubren la vida y no se separan». El texto lo completa con la

150. ComSal 41,3.

151. $83 D Q 71,1$; ComSal 129,4; ComSal 41.

152. $83 D Q 71,1$.

153. ComSal 129,4. 
referencia a Ga 6,2, preguntando: «¿No se dirige el apóstol a ciertos ciervos al decir: Llevad recíprocamente vuestras cargas y así cumpliréis la ley de Cristo?». La novedad está en el aspecto comunitario, apuntado concretamente en el «no se separan» y en el ir «en manada» tanto en tierra como en agua, es decir, interpretando, no sólo en los momentos de especial dificultad, sino también en la vida ordinaria. Los cristianos que han dado ya muerte a los vicios y corren a la fuente divina no lo hacen en solitario, sino en comunidad; el llevar recíprocamente sus cargas les permite mantenerse siempre unidos.

\section{GA 6,2 Y MONACATO}

Entre las formas concretas de llevar recíprocamente las cargas que hemos visto proponer al santo están, pues, la comunión de bienes, la oración, el perdón, la corrección y la imposición de la disciplina mediante el ejercicio de la autoridad. Su simple enumeración dirige la mente a la Regla monástica del santo. A poco que se la conozca se percibe en cada una de esas formas cinco de sus ocho capítulos: $2^{\circ}$ : la oración; $4^{\circ}$ : la corrección fraterna; $5^{\circ}$ : compartir los bienes; $6^{\circ}$ : el perdón de las ofensas; $7^{\circ}$ : criterios de gobierno. Quedan excluidos tres capítulos: el $1^{\circ}$, el $3^{\circ}$ y el $8^{\circ}$. Pero hay que tener en cuenta que, siguiendo la estructura de la Regla presentada por L. Verheijen ${ }^{154}$, el $1^{\circ}$ tiene carácter general y formula el principio fundamental: la unidad de almas y corazones; el $8^{\circ}$ tiene también carácter general en cuanto que engloba y profundiza los anteriores; en consecuencia, de los capítulos que regulan aspectos concretos de la vida monástica, sólo no está representado el $3^{\circ}$ que regula el trato alimenticio que ha de darse a los enfermos físicos, la atención a los cuales salió también en un texto como forma de llevar los unos las cargas de los otros ${ }^{155}$. Por otra parte, el $8^{\circ}$, que fundamenta todos los preceptos anteriores en la caridad y en Cristo, no está muy lejos de lo expuesto, pues se trata de dos aspectos muy presentes en la interpretación agustiniana de $\mathrm{Ga}$ 6,2. Por último, la insistencia que pone en el aspecto comunitario en el ejemplo de los ciervos, se ajusta perfectamente al ideal monástico.

Pero no es necesario buscar vías indirectas para encontrar la relación entre Ga 6,2 y monacato, puesto que la establece explícitamente el mismo san Agustín.

El obispo de Hipona ofrece una interpretación inequívocamente monástica del salmo 132. Le da pie su primer versillo: ;Oh, qué bueno y gozoso habi-

154. Cf. Cf. Verso la belleza spirituale, en La Regola di sant'Agostino, Palermo 1986, pp. 165-166

155. Cf. Sermón 91,7,9. 
tar los hermanos en unidad! Su segundo versillo suena así: Como un ungüento en la cabeza, que baja por la barba, la barba de Aarón, hasta la orla de su vestido. En la interpretación del santo el ungüento simboliza al Espíritu Santo. Aarón, sacerdote de la Ley antigua, es figura del sumo Sacerdote de la Ley nueva y, por tanto, de Cristo, cabeza y cuerpo. El hecho de que el ungüento proceda de la cabeza indica que tiene su origen en Cristo, que lo envió una vez muerto y resucitado. La barba sobre la que desciende es señal de fortaleza; de ahí que la haga símbolo de los primeros cristianos, pues fueron los primeros en habitar en común y sufrir el martirio, dos hechos imposibles sin esa fortaleza.

Desde la barba el ungüento pasa a la orla del vestido. El vestido que cubre el cuerpo del sumo sacerdote lo interpreta como figura de la Iglesia, cuerpo de Cristo. Para apoyar la significación que va a asignar a la orla, señala que representa la conclusión del vestido. Partiendo de esa realidad, contempla dos posibilidades. Asignando a «conclusión» valor cronológico, se podía ver en el hecho una indicación de que, al final de los tiempos, en la Iglesia habrá hermanos que habiten en unidad. Pero no le parece la interpretación más adecuada. La otra consiste en entender «conclusión» como «remate» o «perfección» y entonces significa a los perfectos, los que son capaces de habitar en unidad.

Partiendo de que los perfectos son los que cumplen la ley de Cristo, se pregunta cómo la cumplen los que viven en unidad. La respuesta la encuentra en el texto de $\mathrm{Ga}$ 6,2: Llevad reciprocamente vuestras cargas y así cumpliréis la ley de Cristo. En este precepto paulino ve el significado de la orla del vestido, es decir, el remate o perfección del mismo.

Todavía le queda por dilucidar si se refiere a la orla lateral o a la superior. Descarta la primera para quedarse con la segunda por la razón obvia de que, si el ungüento cae de la barba, difícilmente puede referirse a otra. Se trata, pues, de la que está en la parte superior donde se halla la apertura por la que entra la cabeza. El predicador avanza un poco más y la identifica con los que habitan en unidad, es decir, con los monjes, y con la concordia fraterna. Concordia fraterna por la que entra Cristo, nuestra Cabeza, para vestirse, esto es, para unir a sí a su Iglesia ${ }^{156}$. Por medio de la primera comunidad de Jerusalén que vivía en la unidad, Cristo asoció a sí todos los pueblos para hacer de ellos su vestido, su Iglesia. Esa misma unidad, con idéntica función, sigue haciéndose realidad en los monasterios. «En las comunidades en que los hermanos habitan en unidad, se realiza la unidad de la Iglesia; a partir de allí, 
la unidad se propaga, por así decir, a todos los hombres para unirles a su Cabeza, Cristo. Entonces todos se convierten en miembros de la Iglesia»157.

En síntesis: La Iglesia alcanza su perfección en los que habitan en unidad, es decir, en los monjes. Su argumentación la podemos reducir al siguiente silogismo: la perfección está en el cumplimiento de la ley de Cristo; cumplir la ley de Cristo consiste en llevar recíprocamente los unos las cargas de los otros $(\mathrm{Ga} 6,2)$ o, lo que es lo mismo, en hacer realidad la concordia fraterna; esto lo llevan a cabo los que habitan en unidad (monjes); luego estos representan la perfección de la Iglesia. Sin abertura superior en la túnica, no puede entrar la cabeza; sin concordia fraterna, no puede entrar Cristo en su Iglesia. Queda establecido el valor de la concordia fraterna y, por ello mismo, del monacato, la expresión de esa concordia. A través de los monasterios llega la bendición divina al conjunto de la Iglesia. Así ha dado respuesta a la cuestión que planteaba al comienzo del comentario, de si la bendición que proclama el salmo se refiere a todos los cristianos o sólo a algunos, a partir de los cuales, sin embargo, llegue a los demás ${ }^{158}$.

El texto del ComSal 132 es el único que aplica Ga 6,2 directamente al monacato. El sermón fue predicado con toda probabilidad en el 407, momento álgido de la controversia antidonatista. Como ya se señaló, a ese período corresponden la mayor parte de los textos en que el santo recurre a Ga 6,2. Tiempos nuevos reclaman lecturas nuevas del precepto paulino en que no pensó cuando, siendo aún presbítero, dedicó una quaestio entera a exponerlo. El texto es interpretado ahora, de una parte, en clave más eclesial y antidonatista y, de otra, en clave monástica. De donde cabe deducir el valor apologético, antidonatista en esta circunstancia, que el santo asigna al monacato.

El cisma le ha llevado a reflexionar intensamente sobre la Iglesia. Ga 6,2 le ha ayudado a clarificar cuál debía ser el comportamiento de unos cristianos con otros en aquella situación concreta. Un comportamiento que no existe en la comunidad cristiana de Africa en su conjunto y prueba de ello es la insistencia en recordarlo. Pero pronto lo descubre en el monacato. El ideal paulino que propone a católicos y donatistas, lo proclama hecho realidad en los monasterios. De esa manera, el monasterio se convierte en «espejo» para el conjunto de la Iglesia.

El monasterio le ofrece salida a un problema; le brinda la oportunidad de mostrar que es verdadero lo que dice el salmo 132. Este proclama el gozo de

157. Soeur Marie-Ancilla, La Règle de saint Augustin, Paris 1996, p. 84. Cf. L. VerheiJeN, «L'Enarratio in Psalmum 132 di S. Agostino e la sua concezione del monachesimo», en L. Verheijen, La Regola di S. Agostino. Studi e Ricerche, Palermo 1980, pp. 47-56. 158. cf. ComSal 132,1. 
habitar los hermanos en unidad. A nivel de Iglesia en general no era cierto: los hermanos donatistas y los católicos no experimentaban ese gozo de la unidad, por la sencilla razón de que no estaban unidos. Entonces, ¿queda anulada la verdad del texto sálmico? No; hay un ámbito eclesial donde se hace realidad: el monasterio. También en él los hombres arrastran cada uno sus cargas. También ellos son pecadores, pero, no obstante, mantienen la unidad, no se separan; se ayudan recíprocamente a llevar las respectivas cargas, y así cumplen la ley de Cristo. Ellos son los auténticos ciervos del ejemplo propuesto. La bendición de Dios que significa el gozo de vivir en unidad la recibe la Iglesia primeramente en una parte selecta de sí misma, y de ahí pasa el resto de ella. El monasterio está como prueba de que es posible y de que Dios no deja de derramar esa bendición sobre la Iglesia.

Desde el momento en que el santo asocia tan estrechamente Ga 6,2, perfección y monacato, una comprensión más plena del texto paulino redundará en una comprensión más exacta del monacato agustiniano ${ }^{159}$.

Pío DE LUIS

159. A este respecto, nos parece oportuno traer aquí un texto del Traịcté de la Règle de Saint Augustin del P. A. Le Proust que recoge lo que acabamos de exponer: «... saint Augustin fait tourner toutes les virtus à cette intention charitable de rendre la voie de la perfection évangélique facile au prochain pár un enchaînement des coeurs dans les liens d'une charité réciproque et d'une communauté qui ne vise qu'à unir et lier ensemble sous un même joug les particuliers, pour porter les faix les uns des autres, se rendant ce joug suave, et sa charge légère, et la voie de la perfection et l'accomplissement de la loi aisés, et pour s'entrefaciliter leur salut, et nous y attacher par des liens d'Adam, des liens de la charité, nous facilitant la persévérance, nous aidant à s'y soutenir les uns par les autres: les riches par les pauvres, ceux-ci par les riches, les petits par les grands, les faibles par les forts, les esprits moins solids par la compagnie des sérieux, et réciproquement, formant en l'esprit d'un chacun les pensées, et dans leurs coeurs les sentiments, qu'il doivent avoir les uns des autres pour ce support qui remplit la loi de JésusChrist, et pour leurs assistances mutuelles.

Ainsi toute la fin de sa Règle est la facilité de la perfection évangélique. Son esprit c'est de prendre tellement le joug de Jésus-Christ sur nous, que nous nous le rendions mutuellement suave et nous fassions sa charge légère. Ainsi ce saint Legislateur s'est fait comme ce nourricier d'Ephraim de ces âmes croissantes en perfection, qui les perte sur le bras et les tire avec des cordes d'Adam, des liens touts humains, tout de charité, et dispone le joug qu'il leur impose d'une manière si agréable qu'au lieu de peser sur le cou, il élève leur menton et leur tête. Et cet admirable secret consiste à inspirer à tous cet important conseil de l'Apôtre de suppojter la charge l'un de l'autre en accomplissant la loi de Jésus-Christ» (L. VerHEIJEN, «Il Padre Ange Le Proust e la natura propria della vita monastica agostiniana», en Augustinus XII [1967], p. 486). 